
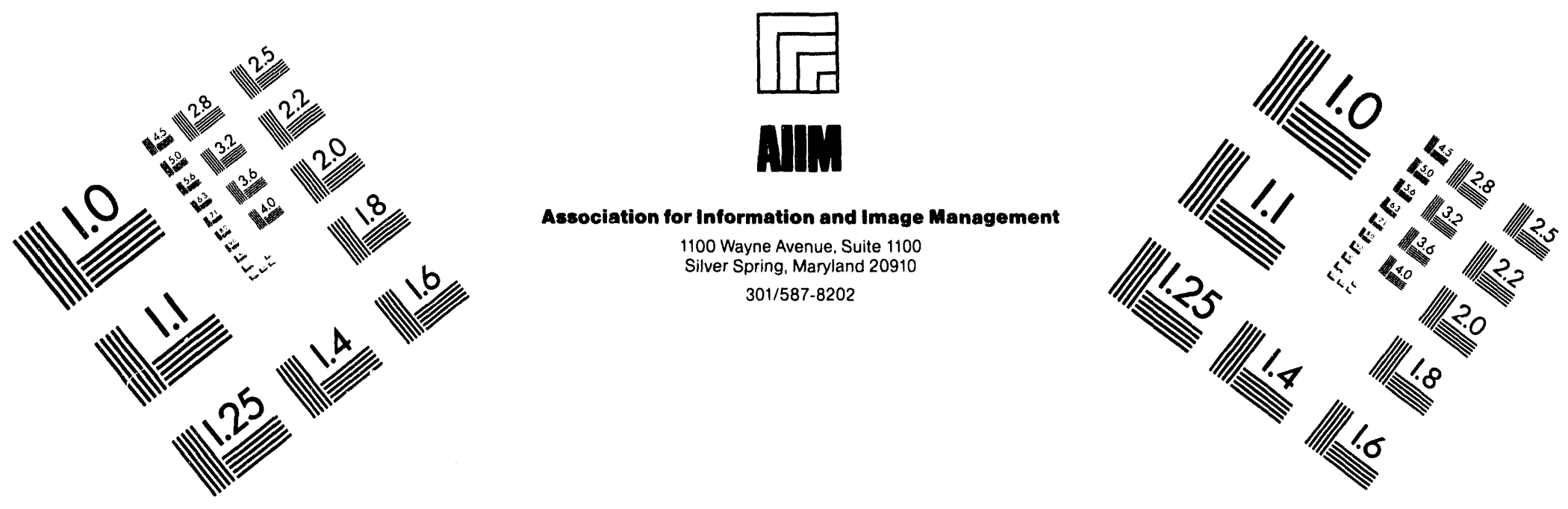

Centimeter

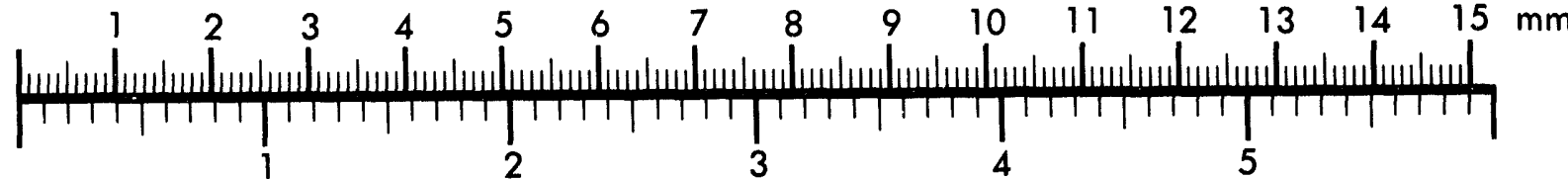
Inches
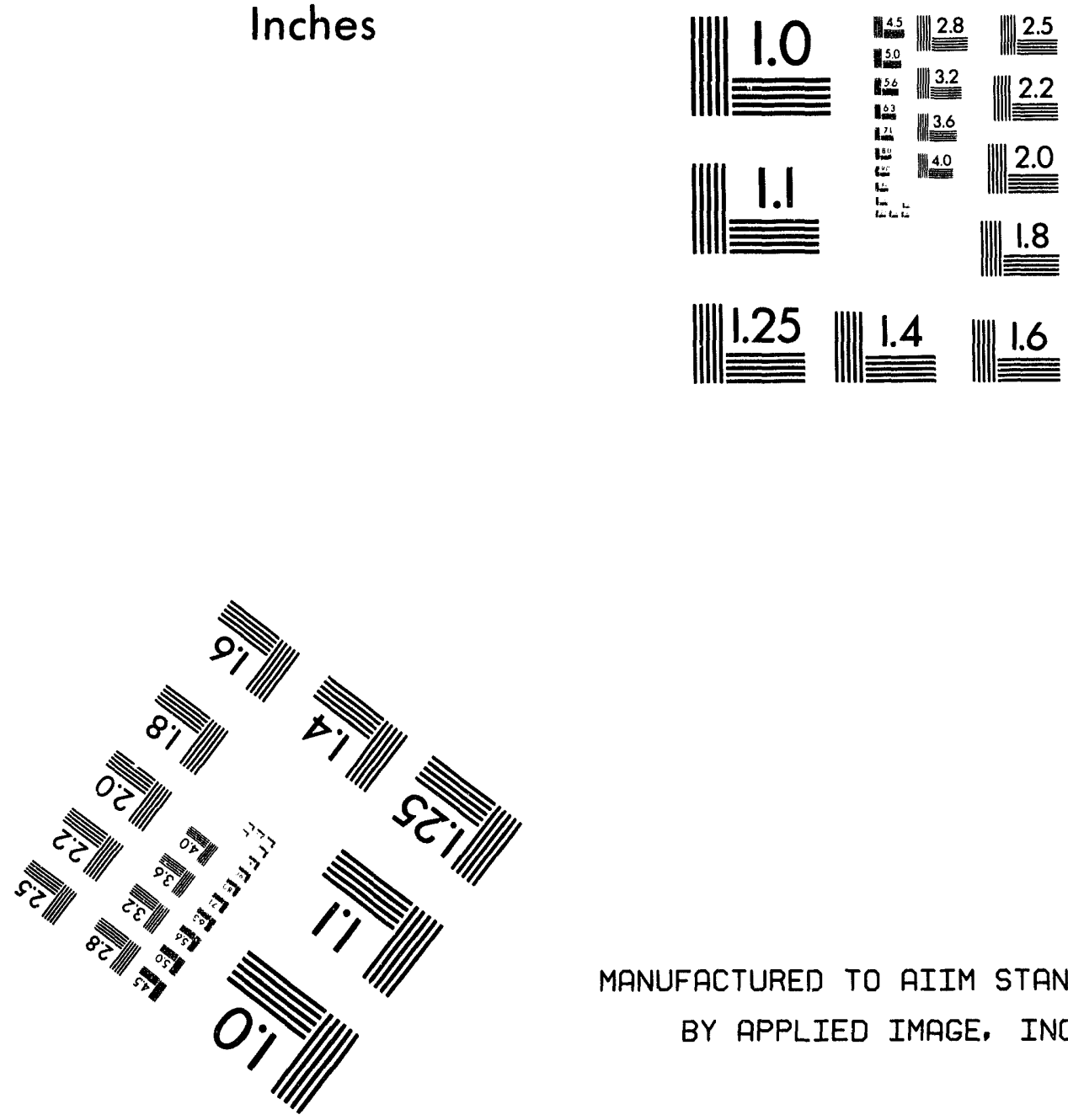

MANUFACTURED TO AIIM STANDARDS

BY APPLIED IMAGE, INC.

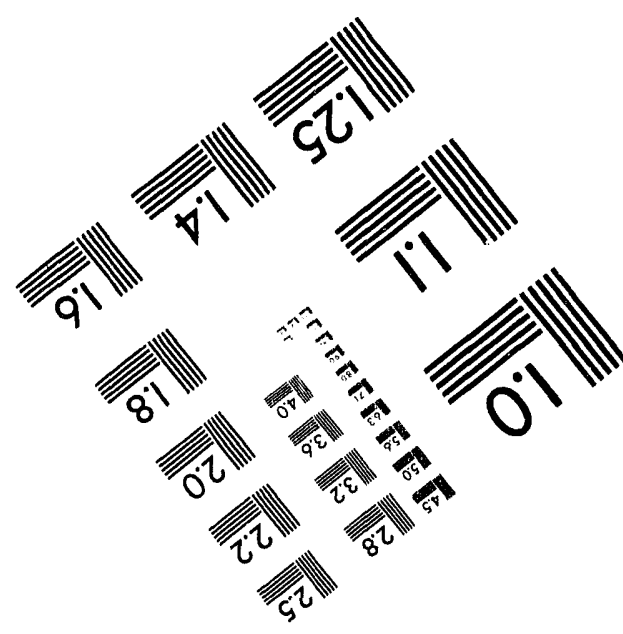



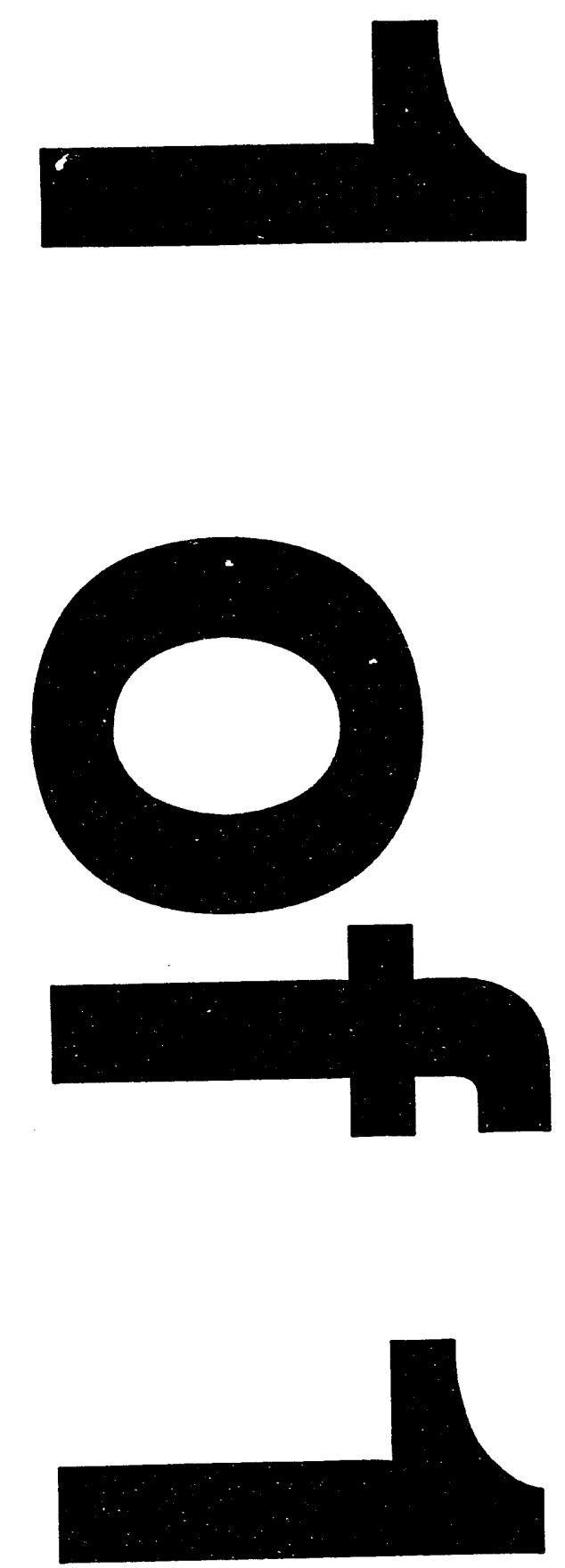


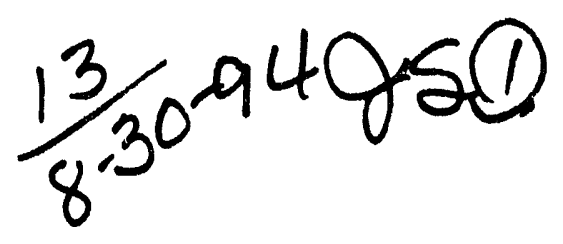

GA-A21592

UC-224

\title{
INSULATOR SEAL FINAL TEST REPORT TFE VERIFICATION PROGRAM
}

\author{
Prepared under \\ CONTRACT DE-AC03-86SF16298 \\ FOR THE SAN FRANCISCO OPERATIONS OFFICE \\ DEPARTMENT OF ENERGY
}

JUNE 1994 


\section{DISCLAIMER}

This report was prepared as an account of work sponsored by the United States Government. Neither the United States nor the United States Department of Energy nor any of their employees, makes any warranty, express or implied, or assumes any legal liability or responsibility for the accuracy, completeness, or usefulness of any information, apparatus, product, or process disclosed, or represents that its use would not infringe privately owned rights. Reference herein to any specific commercial product, process, or service by trade name, mark, manufacturer, or othenwise, does not necessarily constitute or imply its endorsement, recommendation, or favoring by the United States Government or any agency thereof. The views and opinions of authors expressed herein do not necessarily state or reflect those of the United States Government or any agency thereof.

This report has been reproduced directly from the best available copy.

Available to DOE and DOE contractors from the Office of Scientific and Technical Information, P.O. Box 62, Oak Ridge, TN 37831; prices available from (615) 576-8401, FTS 626-8401.

Available to the public from the National Technical Information Service, U.S. Department of Commerce, 5285 Port Royal Rd., Springfield, VA 22161. 
GA-A21592

UC-224

\title{
INSULATOR SEAL FINAL TEST REPORT TFE VERIFICATION PROGRAM
}

\author{
Prepared under \\ CONTRACT DE-ACO3-86SF16298 \\ FOR THE SAN FRANCISCO OPERATIONS OFFICE \\ DEPARTMENT OF ENERGY
}

GENERAL ATOMICS PROJECT 3450

JUNE 1994

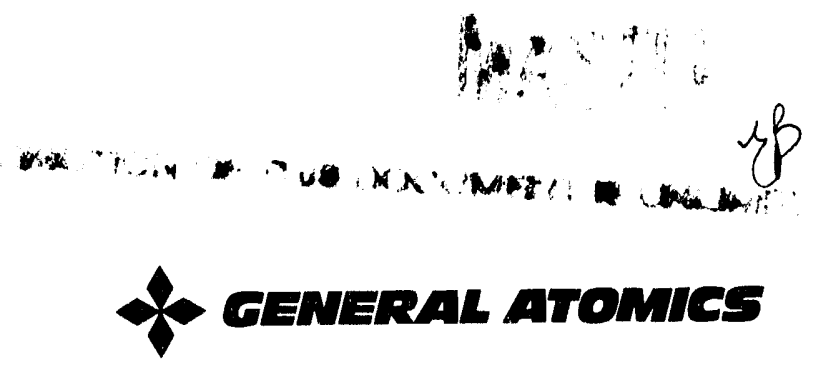




\section{INSULATOR SEALS \\ FINAL TEST REPORT \\ TFE VERIFICATION PROGRAM}

\section{Page}

1. INTRODUCTION

1.1 Objective of TFE Verification Program

1.2 Technical Approach

1.3 Organization of the Program 4

1.4 Structure of Test Program 4

1.4.1 Conceptual Design $\quad 7$

1.4.2 Converter Performance 7

1.4.3 Insulator Seals 7

1.4.4 Sheath Insulators $\quad 7$

1.4.5 Fueled Emitters 7

1.4.6 Cesium Reservoir and Interconnective Components 8

$\begin{array}{lll}1.4 .7 & \text { TFEs } & 8\end{array}$

$\begin{array}{lll}1.5 & \text { Semiannual Progress Reports } & 8\end{array}$

1.6 Final Reports 8

1.7 Westinghouse Hanford Company Reports on Insulator Seals 9

2. OBJECTIVES OF THE TEST PROGRAM 12

2.1 Function of the Insulator Seal 12

2.2 Goals of the Test Program 12

2.3 Requirements of the Insulator Seal 12

2.4 Development Approach/Logic 15

3. FABRICATION DEVELOPMENT 17

3.1 Original Test Matrix 17

$\begin{array}{lll}3.2 & \text { Fabrication } & 20\end{array}$

3.2.1 Taper Insulator Seal 20

3.2.2 Butt Insulator Seal 20

3.2.3 Trilayer Insulator Seal 20

3.3 Process Qualification 24

3.4 Fabrication Results 24

4. EX-REACTOR TEST PROGRAM 26

4.1 Objective 26

4.2 Test Equipment and Test Assembly 26

4.3 Test Procedure 26

4.4 Test Results 30

4.4.1 Taper Insulator Seals 30

4.4.2 Trilayer Insulator Seals 30 
5. IN-REACTOR TEST PROGRAM 36

5.1 Objective 36

5.2 Requirements 36

5.3 Test Description 36

5.4 Postirradiation Examination 38

5.5 Test Results 38

5.5.1 Polycrystalline Alumina Trilayer Seals · 38

5.5.2 Single Crystal Alumina Taper Seal 41

5.5.3 YAG Taper Seals 41

5.5.4 Yttria Trilayer Seals 41

5.5.5 Alumina Trilayer Seals $\quad 44$

6. INSULATOR SEAL SPECIFICATION 48

6.1 Materials/Design 48

6.2 Fabrication Process Description: Reference Insulator Seal 48

6.2.1 Materials 48

6.2.2 Processing 50

6.2.3 Acceptability of Trilayer Insulator Seals 52

6.3 Fabrication Process Description: Backup Insulator Seal 52

6.3.1 Materials 52

6.3.2 Processing 52

6.3.3 Acceptability of Taper Insulator Seals 53

7. REFERENCES 54

APPENDIX A HE LEAK TIGHTNESS REQUIREMENT 56

$\begin{array}{lll}\text { APPENDIX } \mathrm{B} & \text { RESISTANCE REQUIREMENT } & 58\end{array}$ 


\section{INTRODUCTION}

\subsection{Objective of TFE Verification Program}

The program objective was to demonstrate the technology readiness of a Thermionic Fuel Element (TFE) suitable for use as the basic element in a thermionic reactor with electric power output in the 0.5 to $5.0 \mathrm{MW}$ (e) range, and a full-power life of 7 years. A TFE for a megawatt class system is shown on Figure 1-1. Only six cells are shown for simplicity; a megawatt class TFE would have many more cells, the exact number dependent on optimization trade studies.

\section{$1.2 \quad$ Technical Approach}

The TFE Verification Program (TFE-VP) built directly on the technology and data base developed in the 1960s and early 1970s in an AEC/NASA program, and in the SP-100 program conducted in 1983, 1984 and 1985. In the SP-100 program, the attractive features of thermionic power conversion technology were recognized but concern was expressed over the lack of fast reactor irradiation data. The TFE-VP addressed that concern.

The technical approach followed to achieve the program objective is shown on Fig. 1-2. Five prior programs form the basis for the TFE-VP:

1) AEC/NASA program of the 1960 s and early 1970 s.

1) SP-100 concept development program (Ref. 1-1).

3) SP-100 thermionic technology program (Ref. 1-2).

4) Thermionic irradiations program in TRIGA in FY-86 (Ref. 1-3).

5) Thermionic Technology Program in 1986 and 1987 (Refs. 1-4, 1-5).

These programs provided both the systems and technology expertise necessary to design and demonstrate a megawatt class TFE.

A TFE was designed that met the reliability and lifetime requirements for a 2 MW(e) conceptual reactor design. Analysis showed that this TFE could be used over the range of 0.5 to 5 megawatts. This was used as the basis for designing components for test and evaluation. The demonstration of a 7-year component lifetime capability was through the combined use of analytical models and accelerated, confirmatory tests in a fast test reactor. Iterative testing was performed where the results of one test series led to evolutionary improvements in the next test specimens.

The TFE components underwent screening and initial development testing in ex-reactor tests. Several design and materials options were considered for each component. As screening tests permitted, down selection occurred.

In parallel with ex-reactor testing, and fast reactor component testing, components were integrated into a TFE and tested in the TRIGA test reactor at General Atomics (GA). Realtime 


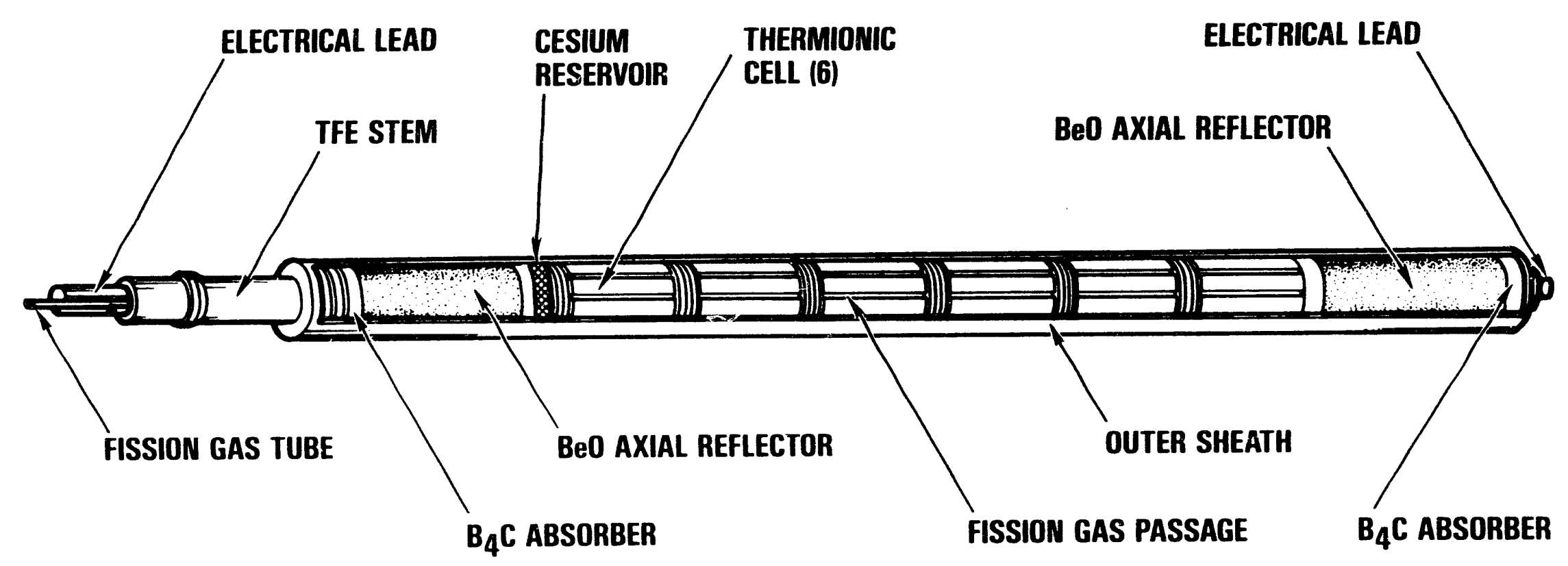

Figure 1-1. TFE for Megawatt Class System 


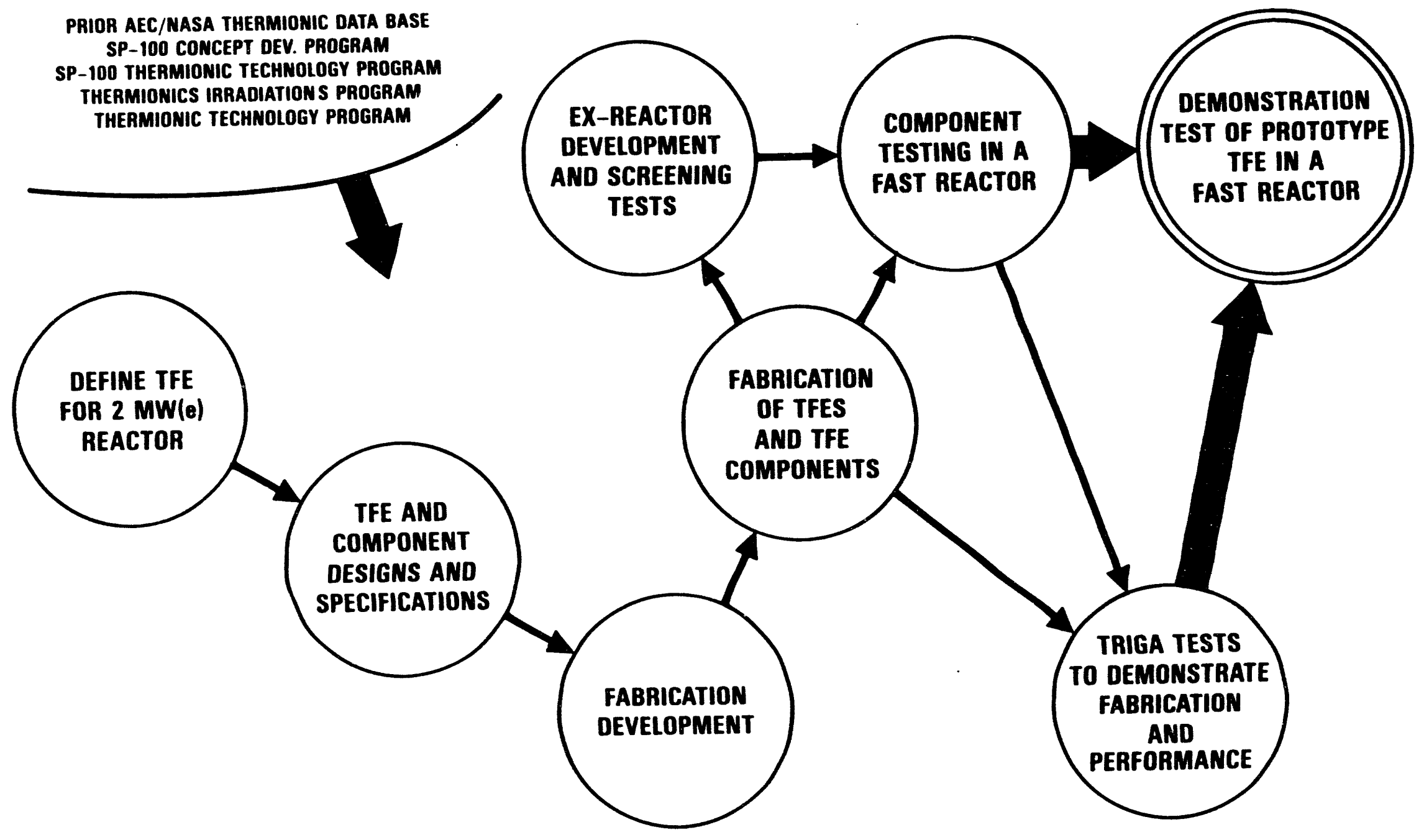

Figure 1-2. Logic to Demonstrate Technology Readiness of Megawatt Class TFE 
testing of partial length TFEs was used to test support, alignment and interconnective TFE components, and to verify TFE performance in-reactor with integral cesium reservoirs. Realtime testing was also used to verify the relation between TFE performance and fueled emitter swelling, to test the durability of intercell insulation, to check temperature distributions, and to verify the adequacy over time of the fission gas venting channels.

Predictions of TFE lifetime rested primarily on the accelerated component testing results, as correlated and extended to realtime by the use of analytical models.

\subsection{Organization of the Program}

Contracting Agency: Department of Energy, San Francisco Operations Office

Prime Contractor: General Atomics (GA)

Subcontractors:

ThermoTrex Corporation (TTC), a subsidiary of Thermo Electron Corporation

Rasor Associates, Incorporated (RAI)

Space Power Incorporated (SPI)

Fast reactor testing manager:

Westinghouse Hanford Corporation (WHC)

Fast reactor facilities:

Fast Flux Test Reactor (FFTF), with testing managed by WHC.

Experimental Breeder Reactor-II (EBR-II), with testing managed by Argonne

National Laboratory-West (ANL-W)

Technical oversight for DOE: Los Alamos National Laboratory (LANL).

\section{$1.4 \quad$ Structure of Test Program}

The TFE-VP was broken down into 7 tasks, generally corresponding to the components of a TFE. Figure 1-3 shows a thermionic cell with the various components identified.

Figure 1-4 shows a one cell TFE fabricated for test in the program. A multi-cell TFE has 2 or more cells in series.

When compared to Figure 1-1, it is clear that this test article is not quite prototypical. The test conditions dictate the design to some extent. Also, the test approach is to first test simple TFEs and then gradually test TFEs more prototypic.

For each component, the work involved: 


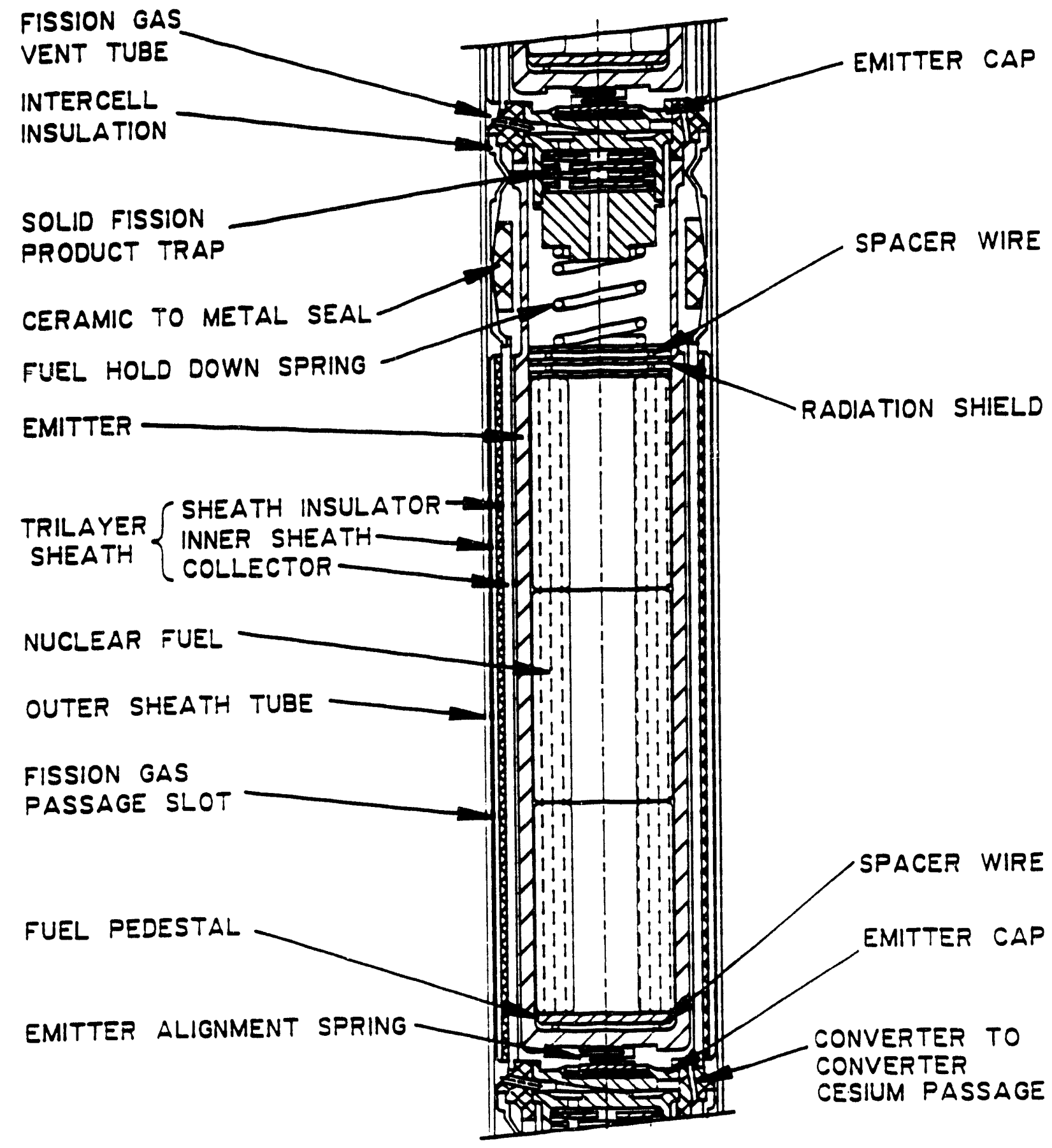

Figure 1-3. Thermionic Cell 


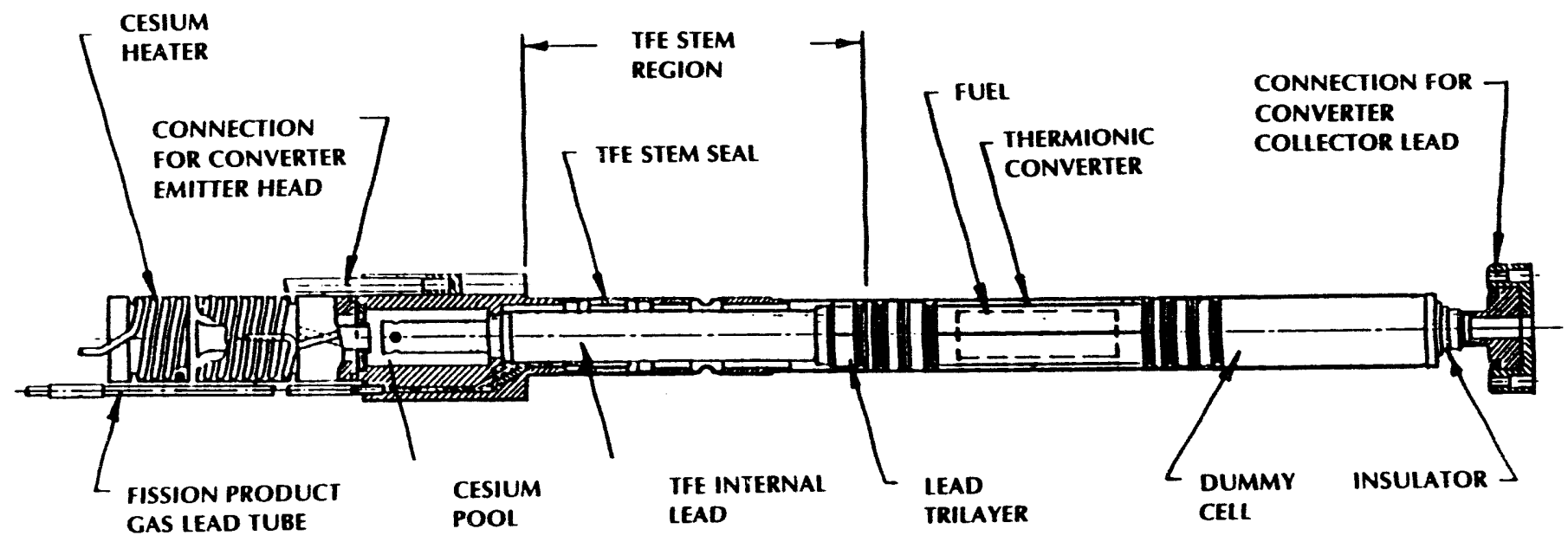

Figure 1-4. One Cell TFE Test in TFE Verification Program 
1) Component design and analyses

2) Materials evaluation and selection

3) Performance testing

4) Life testing, both accelerated and real time.

In addition, performance models were developed for converter performance, fueled emitters and cesium reservoirs.

A brief description of each task is given below. For each of the component tasks, fabrication process specifications were developed and materials were chosen.

1.4.1 Conceptual Design. A TFE optimized for a $2 \mathrm{MW}$ (e) system was designed. Its scalability over the range of $500 \mathrm{~kW}$ to $5 \mathrm{MW}$ was demonstrated.

1.4.2 Converter Performance. The performance of converters of interest for megawatt class systems was measuredd and existing models on converter performance were refined.

1.4.3 Insulator Seals. The insulator seal isolates the space filled with gaseous fission products from the cesium filled interelectrode gap. It also assures that electrons flow from the collector of one cell to the ennitter of an axially adjacent cell.

1.4.4 Sheath Insulators. The sheath insulator is a structure composed of 3 layers:

o The inner layer is the collector.

o The middle layer is an insulator electrically isolating the collector from the reactor coolant and structure. It also must conduct reject heat to the reactor coolant.

o The cutter metallic layer assures the structural integrity of the sheath.

1.4.5 Fueled Emitters. The fueled emitter is the emitter component inside of which are the following components:

- $\quad \mathrm{UO}_{2}$ fuel.

o Fuel holddown device to prevent damage to the cell during launch and ascent.

o Fission product trapping components to prevent solid and condensable fission products from exiting the cell.

o Heat shields to protect the upper and lower parts of the emitter from the high temperatures of the $\mathrm{UO}_{2}$ fuel. 


\subsubsection{Cesium Reservoir and Interconnective Components}

The cesium reservoir provides cesium vapor to the interelectrode gap. A graphite cesium reservoir was demonstrated in the program.

Interconnective components are those metal parts and insulators which are necessary to attach one cell in series with another.

\subsubsection{TFES}

The TFE is an axial series of one or more cells. It also contains a cesium reservoir. TFEs with one, three and six cells were fabricated and tested.

The TFEs fabricated under the TFE-VP are designated the " $H$ " series TFEs, being the next series following the "E", "F" and "G" series which were studied in the 1960s and 1970s. The E-series TFEs had an emitter diameter of 0.625 inch; the F-series, 1.1 inches; and the $\mathrm{H}$ series, 0.5 inches.

A specific TFE has a designation $x H y$, the " $x$ " being the number of cells in the TFE and the "y" being the specific TFE in question. For example, the TFEs fabricated and tested in the program were:

TFE-1H1, the first of the 1-cell TFEs.

TFE-1H2, the second of the 1-cell TFEs.

TFE-1H3, the third of the 1-cell TFEs.

TFE-3H1, the first of the 3-cell TFEs.

TFE-3H5, the fifth of the 3-cell TFEs. Numbers 2,3 and 4 were eliminated early in the program.

TFE-6H1, the first of the 6-cell TFEs.

\subsection{Semiannual Progress Reports}

Semiannual progress reports provide a running account of technical progress which reflects the work done at GA, TTC, RAI and SPI. These reports also summarize the status and results of the irradiation program at WHC, ANL-W and LANL.

Table 1-1 shows a complete list of all semiannual progress reports.

\section{$1.6 \quad$ Final Reports}

Final test reports give details on each of the major components outlined in Section 1.4. A list of these final reports is given in Table 1-2. It is assumed in these reports that the reader is familiar with thermionic technology and the structure and operation of thermionic fuel elements and their components. 


\subsection{Westinghouse Hanford Company Reports on Insulator Seals}

WHC issued several reports dealing with the testing and postirradiation examination of insulator seals. These are listed in Table 1-3. The ı eader is referred to these reports for detail on the irradiation of cesium reservoirs and their subsequent postirradiation examination (PIE).

Table 1-1

\section{SEMIANNUAL PROGRESS REPORTS}

\begin{tabular}{|l|l|c||}
\hline \multicolumn{1}{|c|}{ Period Ending } & \multicolumn{1}{|c|}{ Date Issued } & Report Number \\
\hline March 31, 1987 & April 1987 & GA-A18780 \\
September 30, 1987 & March 1988 & GA-A19115 \\
April 30, 1988 & June 1988 & GA-A19269 \\
October 31, 1988 & January 1989 & GA-A19412 \\
April 30, 1989 & September 1989 & GA-A19666 \\
September 30, 1989 & March 1990 & GA-A19876 \\
March 31, 1990 & July 1990 & GA-A20119 \\
September 30, 1990 & January 1991 & GA-A20335 \\
March 31, 1991 & April 1991 & GA-A20493 \\
September 30, 1991 & December 1991 & GA-A20804 \\
March 31, 1992 & April 1992 & GA-A20911 \\
September 30, 1992 & January 1993 & GA-A21210 \\
March 31, 1993 & May 1993 & GA-A21326 \\
September 30,1993 & January 1994 & GA-A21511 \\
\hline
\end{tabular}

Table 1-2

FINAL TEST REPORTS OF TFE VERIFICATION PROGRAM

\begin{tabular}{|l|c|}
\hline Report Title & Document No. \\
\hline Conceptual Design & GA-A21590 \\
Converter Peformance Final Test Report & GA-A21591 \\
Insulator Seal Final Test Report & GA-A21592 \\
Sheath Insulator Final Test Report & GA-A21593 \\
Fueled Emitter Final Test Report & GA-A21594 \\
Cesium Reservoir and Interconnective Components Final Test Report & GA-A21595 \\
TFE Performance Final Test Report & GA-A21596 \\
TFE Design Package & GA-A21597 \\
Fabrication Process Specifications & GA-A21734 \\
\hline
\end{tabular}


Table 1-3

\section{WESTINGHOUSE HANFORD COMFANY REPORTS ON INSULATOR SEAL TESTING}

\section{Test Documentation}

1. Williams, L. S., "Test Design Description for the Materials Open Test Assembly HM115 (MOTA-1E)", Experiment Description - Volume II, HEDL-TC-2851, July 1986.

2. Williams, L. S., "Final Data Package As-Built Documentation for the Installation of the Test Train into the Materials Open Test Assembly Vehicle - HM115 (MOTA1E)", HEDL-TC-2855, July 1986.

3. Williams, L. S., "Test Design Description for the Materials Open Test Assembly HM116 (MOTA-1F)", Experiment Description - Volume II, WHC-SP-0028, August 1987.

4. Williams, L. S., "Final Data Package As-Built Documentation for the Installation of the Test Train into the Materials Open Test Assembly Vehicle - HM116 (MOTA-1F)" WHC-SP-0085, September 1987.

5. Engineering Test Plan for EBR-II Tests UFAC-2B and UFAC-3, WHC-SP-0469, May 1989.

6. Experiment Description and Safety Analysis for EBR-II Tests UFAC-2B and UFAC3, WHC-SP-0470, July 1989.

6. Supporting Analysis for UFAC Tests in EBR-II, WHC-SD-SP-DA-002, December 1989.

7. Engineering Test Plan (ETP) for UCA-3, WHC-SD-SP-DB-001, August 1990.

8. QA and As-Built Data Package for UCA-3 Experiment (Capsule SC3-3), WHC-SDSP-DP-001, November 1991.

9. QA and As-Built Data Package for UCA-3 Experiment (Capsule SC3-4, SC3-5 and SC3-6), WHC-SD-SP-DP-002, April 1991.

\section{Test Data Reports}

1. Lawrence, L. A., N. S. Cannon and K. E. Ard, "Irradiation and Examination of the Thermionic Fuel Element (TFE) Verification Program UCA-1 Samples", WHC-SP0585, May 1990. 
2. Lawrence, L. A., K. E. Ard and D. M. Paxton, "Irradiation and Examinations of the Thermionic Fuel Element (TFE) Verification Program UCA-2 Samples", WHC-SP0656, June 1991.

3. Lawrence, L. A. and D. M. Paxton, "Irradiation and Examinations of the Thermionic Fuel Element (TFE) Verification Program UCA-3 Samples", WHC-SP-1055, September 1993.

4. Paxton, D. M. and L. A. Lawrence, "Irradiation and Nondestructive Examination (NDE) of the Thermionic Fuel Element (TFE) Verification Program UFAC SC3-2 Seal Insulator Samples", WHC-SP-0674, June 1991.

5. Paxton, D. M. and L. A. Lawrence, "Irradiation and Metallography of the Thermionic Fuel Element (TFE) Verification Program UCA-2 Samples", WHC-SP0658, February 1991.

6. Cannon, N. S., "Thermal Property Measurements of Unirradiated Thermionic Fuel Element (TFE) Sheath Insulators", WHC-SP-0711, November 1991. 


\section{OBJECTIVES OF THE TEST PROGRAM}

\section{$2.1 \quad$ Function of the Insulator Seal}

The insulator seal is a ceramic-to-metal seal, the functions of which in a thermionic cell are to provide a hermetic seal between the cesium and fission gas spaces, and to electrically isolate the emitter from the collector. Figure 2-1 shows the location and types of insulators used in a thermionic cell.

\subsection{Goals of the Test Program}

The goals of the insulator seal test program were to demonstrate that suitable ceramic materials and seal fabrication processes are available, and to validate the performance of the insulator seal for TFE-VP requirements. In particular the goals were:

1) Produce designs for the insulator seal.

2) Develop required fabrication processes and document with process specifications.

3) Fabricate insulator seals for ex-reactor testing to determine their electrical characteristics and cesium compatibility.

4) Fabricate insulator seals for in-reactor testing for UCA-1, UCA-2, UCA-3, and UFAC-3.

5) Verify the performance characteristics and lifetimes associated with insulator seals by means of ex-reactor and in-reactor testing. Perform postirradiation examinations of the insulator seals and use the test results to improve the seal design.

\subsection{Requirements of the Insulator Seal}

The TFE-VP placed the following requirements on the insulator seal:

1) Insulator operating temperature:

1070 to $1150 \mathrm{~K}$

2) Nominal fast fluence, $\mathrm{E}>0.1 \mathrm{MeV}$ :

$2.7 \times 10^{22} \mathrm{n} / \mathrm{cm}^{2}$

3) Nominal aprlied voltage:

0.49 volts

Maximum applied voltage:

0.63 volts

4) Operating environment:

1-3 torr Cs and fission gases 


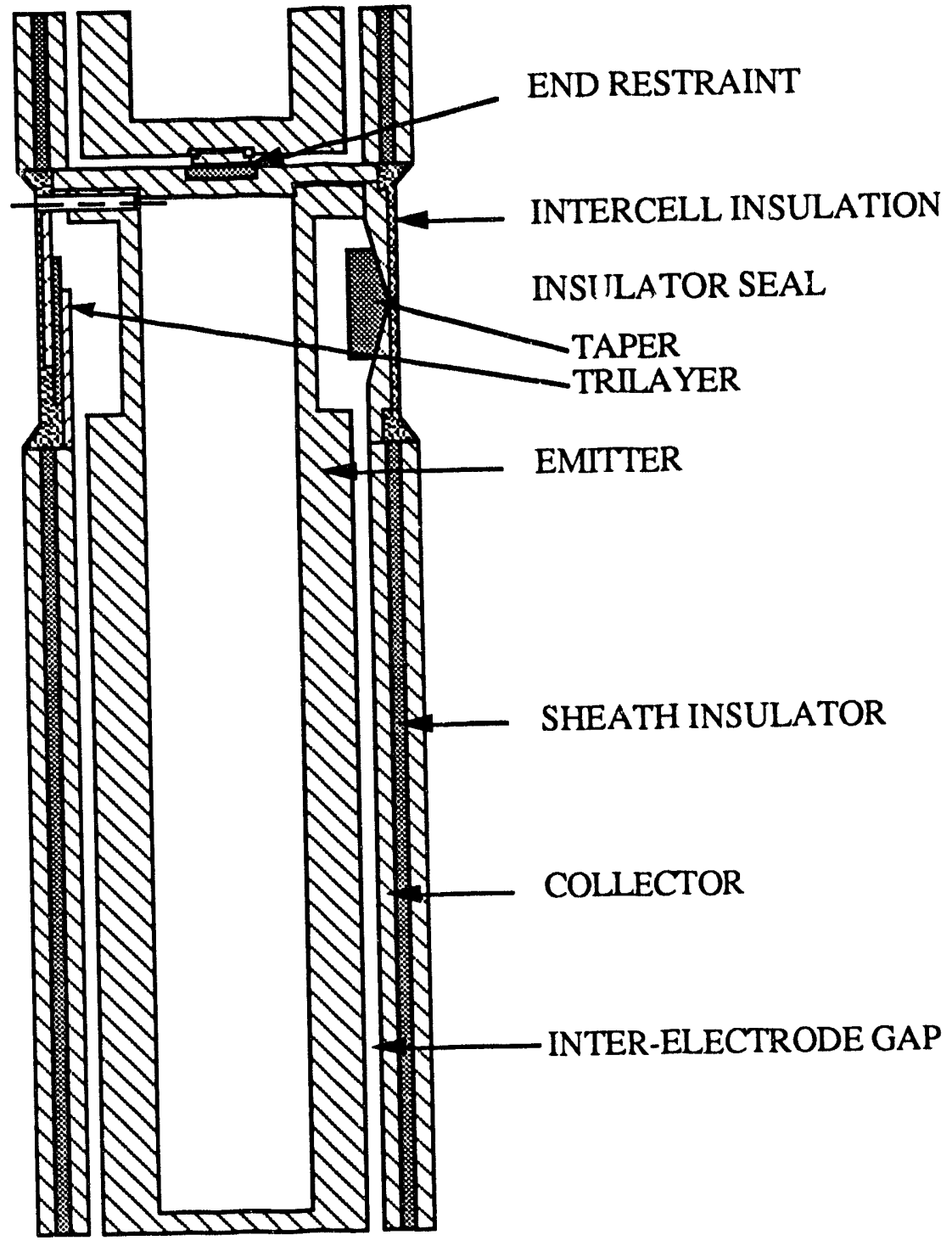

Figure 2-1. Thermionic Cell Showing Insulator Locations 
5) Leak tightness:

6) Electrical resistance:

7) Lifetime:
$<2 \times 10^{-11} \mathrm{std} \mathrm{cc} / \mathrm{s}$, as fabricated $<5 \times 10^{-5} \mathrm{std} \mathrm{cc/s}$, at end-of-life

$>10$ Ohms $(1150 \mathrm{~K})$

$\geq 7$ years

The He leak tightness requirement at end-of-life is based on an intercalated Csgraphite reservoir with 0.1 grams of graphite and first stage cesium loading. The leak tightness requirement calculations are given in Appendix A.

The insulator seal resistance requirement calculations are given in Appendix B. An insulator seal with a $10 \mathrm{ohms}$ resistance will limit the power dissipated in the insulator seal to less than $0.1 \%$ of the total TFE power. Ten ohms translate into a resistivity of $2.4 \times 10^{1} \mathrm{ohm}-\mathrm{cm}$ for a taper seal or $3.6 \times 10^{2} \mathrm{ohm}-\mathrm{cm}$ trilayer seal at $1150 \mathrm{~K}$.

To satisfy the TFE verification program design requirements, the insulator seal must meet the following additional derivative requirements:

1) Minimal neutron damage effects. The fast neutron fluence should lead to minimal changes in the electrical properties of the insulator seal. In addition, the insulator seal should remain leak tight. This condition implies that the volumetric swelling of the insulator should be low.

2) Electrical breakdown field. The insulator seal should withstand a potential difference of 0.63 volts without exhibiting breakdown.

3) Chemical compatibility and stability. The insulator material should be chemically compatible with adjacent metallic electrode material. It should be compatible with cesium vapor as well as with the fission gases expected form the $\mathrm{UO}_{2}$ fuel.

4) Minimal electrolytic degradation. Electrolysis of the insulator should be negligible. An insulator material which exhibits an ionic conductivity of $<10^{-10}(\mathrm{ohm}-\mathrm{cm})^{-1}$ at $1150 \mathrm{~K}$ will exhibit minimal electrolytic degradation.

5) Acceptable vapor ressure/melting point. The insulator material melting temperature and vapor pressure at $1150 \mathrm{~K}$ should be compatible with the design requirements. A melting point in excess of $2000 \mathrm{~K}$ and a vapor pressure at $1150 \mathrm{~K}$ of $<10^{-10}$ torr are acceptable.

6) Acceptable size. The overall length of the insulator seal should be dimensionally compatible with the reference TFE design length. 


\subsection{Development Approach/Logic}

The overall development approach/logic for the insulator seal program is shown in Fig. 2-2. Solid boxes represent insulator seal activities while supporting activities are indicated by the dashed boxes. Initial insulator seal requirements were established to define materials and designs. Data from previous fast neutron irradiation tests, compatibility tests, and previous seal design experience were also used. Test specimens were fabricated for exreactor and in-reactor testing and for actual incorporation and testing in the H-series TFEs. If the in-reactor and ex-reactor testing results indicated that the properties of the insulator seal were acceptable, then further specimens were prepared for more extensive testing. Materials and designs with unacceptable properties were dropped.

The major outputs from the development work were insulator materials, seal designs, fabrication processes, and performance characteristics.

The in-reactor test program was comprised of several batches of test specimens, as shown in Table 2-1. Uninstrumented Component Accelerated (UCA) tests were conducted in the FFTF in a Materials Open Test Assembly (MOTA). UCA tests were also run in the EBR-II test reactor.

In addition, test specimens were included in the Uninstrumented Fast Reactor Accelerated Component (UFAC) tests in EBR-II. The UFAC tests were designed primarily to test fueled emitters but it was possible to test insulator components at the same time.

Table 2-1

IN-REACTOR TEST STRATEGY

\begin{tabular}{||l|l|l|c||}
\hline Test Designation & Test Reactor & \multicolumn{1}{|c|}{ Test Objectives } & $\begin{array}{c}\text { Maximum Fluence } \\
\left(10^{22} \mathrm{n} / \mathrm{cm}^{2}\right)\end{array}$ \\
\hline UCA-1 & FFTF & First screening test & 7.2 \\
UCA-2 & FFTF & Second screening test & 5.5 \\
UCA-3 & & & \\
Batch A & EBR-II & $\mathrm{Al}_{2} \mathrm{O}_{3}$ taper seal test & 1.5 \\
Batch B & EBR-II & $\mathrm{Al}_{2} \mathrm{O}_{3}$ trilayer seal test & 1.8 \\
UFAC-3 & EBR-II & Taper seal screening test & 2.8 \\
\hline
\end{tabular}




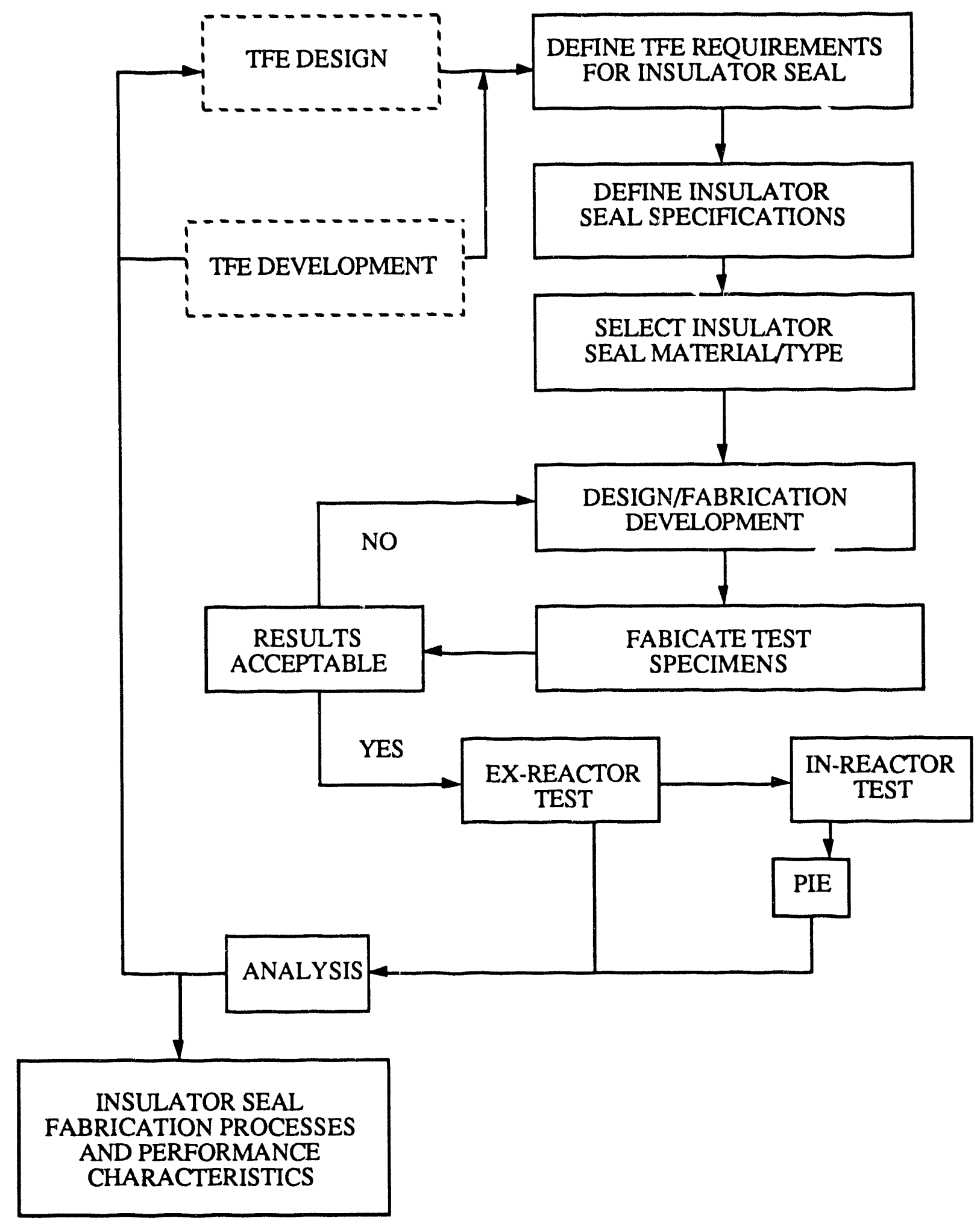

Figure 2-2. Development/Approach Logic for Insulator Seals 


\section{FABRICATION DEVELOPMENT}

\subsection{Original Test Matrix}

included:

Ceramic materials that were the focus of the insulator seal development effort

1) Aluminum oxide (alumina - $\mathrm{Al}_{2} \mathrm{O}_{3}$ ), single crystal and polycrystalline.

2) Yttrium oxide (yttria $-\mathrm{Y}_{2} \mathrm{O}_{3}$ ), polycrystalline.

3) Yttrium aluminum garnet $\left(\mathrm{YAG}-\mathrm{Y}_{3} \mathrm{Al}_{5} \mathrm{O}_{12}\right)$, single crystal and polycrystalline.

The choice of ceramic materials was guided by the requirements outlined in Section 2.3. Properties of interest for the three selected materials are given in Table 3-1. All the insulators listed have resistivities above that required for acceptable performance.

Electrolytic degradation is minimal because of the low ionic conductivity, high resistivity, of the candidate materials.

Table 3-1

PROPERTIES OF CANDIDATE INSULATOR SEAL MATERIALS

\begin{tabular}{||l|c|c|c||}
\hline Material & $\begin{array}{c}\text { Volumerric Swelling } \\
(\%)\end{array}$ & $\begin{array}{c}\text { Coefficient of } \\
\text { Thermal Expansion } \\
\left(10^{-6} / \mathrm{K}(1150 \mathrm{~K})\right.\end{array}$ & $\begin{array}{c}\text { Resistivity (Ohm-cm) } \\
(1150 \mathrm{~K})\end{array}$ \\
\hline $\mathrm{Al}_{2} \mathrm{O}_{3}$ & $3-10^{*}$ & 9.5 (Ref. 3-2) & $10^{9}$ (Ref. 3-4) \\
$\mathrm{Y}_{2} \mathrm{O}_{3}$ & $0.5-1.5^{*}$ & 8.9 (Ref. 3-2) & $10^{7}$ (Ref. 3-3) \\
$\mathrm{Y}_{3} \mathrm{Al}_{5} \mathrm{O}_{12}$ & $<0.5^{*}$ & 8.0 (Ref. 3-6) & $10^{8}$ (Ref. 3-5) \\
$\mathrm{Nb}$ & & 8.7 (Ref. 3-2) & \\
\hline
\end{tabular}

"Irradiation to $1-2 \times 10^{22} \mathrm{n} / \mathrm{cm}^{2}$ at $925 \mathrm{~K}$ and $1100 \mathrm{~K}, \mathrm{E}>0.1 \mathrm{MeV}$ (Ref. 3-1).

Data on the volumetric swelling from neutron fluence suggest that alumina may not remain hermetic over the seven year lifetime of the insulator seal. Hence, yttria and YAG, two materials that exhibit less swelling than alumina, were the focus of the initial development effort in the TFE-VP. However, extensive and favorable data on alumina exist. Taper polycrystalline alumina insulator seals were used in $E$ and $F$ (pre 1983) series TFEs and tested in the TRIGA reactor for up to 12,500 hours without failure. Hence, alumina was also studied in the early testing. 
In addition to meeting the neutron damage requirement, the insulators must be chemically compatible with cesium vapor as well as chemically and mechanically compatible with niobium. The cesium compatibility was identified as the sole feasibility issue in the SP-100 Thermionic Technology Program (Ref. 1-2). The effort concentrated on establishing the cesium compatibility in accelerated tests at higher than design temperatures and cesium pressures. Samples of single crystal alumina, polycrystalline yttria and polycrystalline YAG were exposed to 60 torr of cesium vapor for 200 hours at 1100,1250 and $1400 \mathrm{~K}$. None of the samples showed any evidence of being attacked by cesium.

Yttria also has a favorable thermal expansion match to niobium. However there have been reports of a possible reaction of niobium with both yttria and YAG (Ref. 1-2).

The seal designs that were the focus of the insulator seal development are shown schematically in Fig. 3-1 and included:

1) Taper seal.

2) Butt seal.

3) Trilayer seal.

The taper seal has been extensively developed and used in prior programs. It is easy to fabricate and is robust and strong.

The butt seal has the potential for being short, and a short space between cells in a TFE is desirable from a neutron criticality point of view. fabricate.

The trilayer seal is a derivative of the sheath insulator technology and is easy to

Table 3-2 gives the initial insulator seal test matrix showing seal design and materials.

Table 3-2

INITIAL INSULATOR SEAL TEST MATRIX

\begin{tabular}{||c|c|c|c|}
\hline Material & Taper & Butt & Trilayer \\
\hline Alumina S.C. & $\mathrm{X}$ & $\mathrm{X}$ & $\mathrm{X}$ \\
Alumina P.C. & $\mathrm{X}$ & & $\mathrm{X}$ \\
Yttria P.C. & $\mathrm{X}$ & & $\mathrm{X}$ \\
YAG S.C. & $\mathrm{X}$ & & \\
YAG P.C. & $\mathrm{X}$ & & $\mathrm{X}$ \\
\hline
\end{tabular}

S.C. - Single Crystal

P.C. - Polycrystalline 

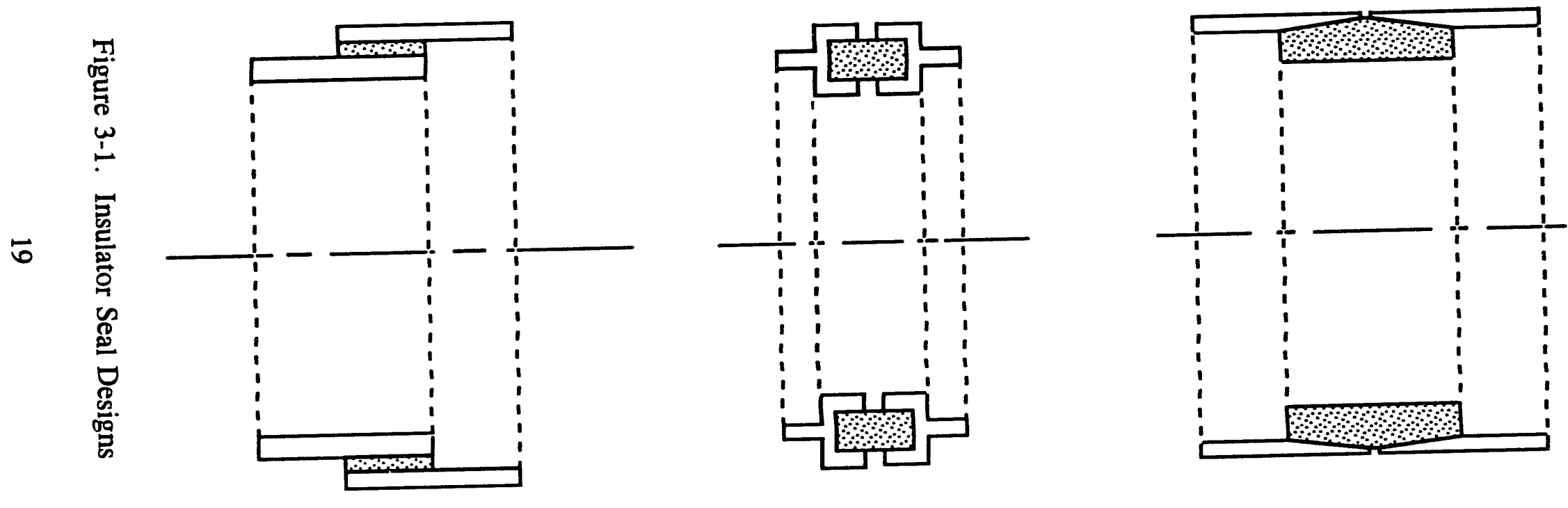

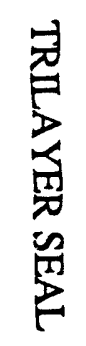

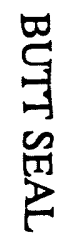

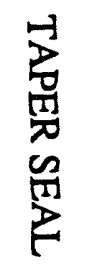




\section{$3.2 \quad$ Fabrication}

\subsubsection{Taper Insulator Seal}

Figure 3-2 shows the major steps in the fabrication of the taper insulator seal. The starting ceramic is either a polycrystalline or single crystal slug or tube, of alumina, yttria or YAG machined to the taper ring configuration. The polycrystalline slug is made by consolidating and sintering to $>98 \%$ theoretical density high purity oxide powder. The taper ceramic ring is metallized with a tungsten- $2 \%$ yttria metallizer to form a highly adherent coating to which niobium can be brazed. An intermediate chemical vapor deposition (CVD) tungsten coating is required between the metallizer and braze to protect the unmetallized areas from reacting with the braze alloy. The metallized ceramic ring is brazed to niobium skirts using a niobium-vandium braze $(35 \% \mathrm{Nb}-65 \% \mathrm{~V})$. The taper seal is machined to its final dimensions and any metallizer or braze alloy are removed from exposed insulating surfaces. The finished seal is process qualified to test seal integrity.

Developmental work was done on brazing the taper seal with lower temperature braze alloys to reduce thermal stresses that are associated with the fabrication process.

\subsubsection{Butt Insulator Seal}

Figure 3-3 shows the major steps in the fabrication of the butt insulator seal. The starting ceramic material is an alumina single crystal (sapphire), and is machined to the butt ring configuration. The ceramic ring is metallized with a tungsten- $2 \%$ yttria metallizer. The metallized ring is gas pressure bonded $\left(1550^{\circ} \mathrm{C}\right.$ and $\left.10,000 \mathrm{psi}\right)$ to niobium. The seal is machined to the butt seal configuration. The finished seal is process qualified to test seal integrity.

\subsubsection{Trilayer Insulator Seal}

Figure 3-4 shows the major steps in the fabrication of the graded trilayer insulator seal. The fabrication technology is identical to that of the sheath insulator. The starting ceramic materials, alumina, yttria or YAG, are high purity oxide powders. The seal is fabricated by plasma spraying niobium powder and the ceramic powder onto a niobium mandrel. To match the difference in coefficient of thermal expansion between the niobium mandrel and ceramic, the ceramic and niobium powders are plasma-sprayed in such a way as to produce a gradation from pure niobium to pure ceramic and back to pure niobium. A niobium sheath is placed over the last plasma spayed layer of niobium and the assembly is gas pressure bonded at $1550^{\circ} \mathrm{C}$ and $10,000 \mathrm{psi}$. The resulting structure is then machined to the trilayer seal configuration. The finished seal is process qualified to test seal integrity.

Figure 3-5 shows the major steps in the fabrication of the slip cast cermet trilayer seal, a process developed by TTC. The ceramic powder, alumina, yttria or YAG, is mixed with 5 to 10 volume percent niobium powder or spheres and cast into a hollow cylinder. 


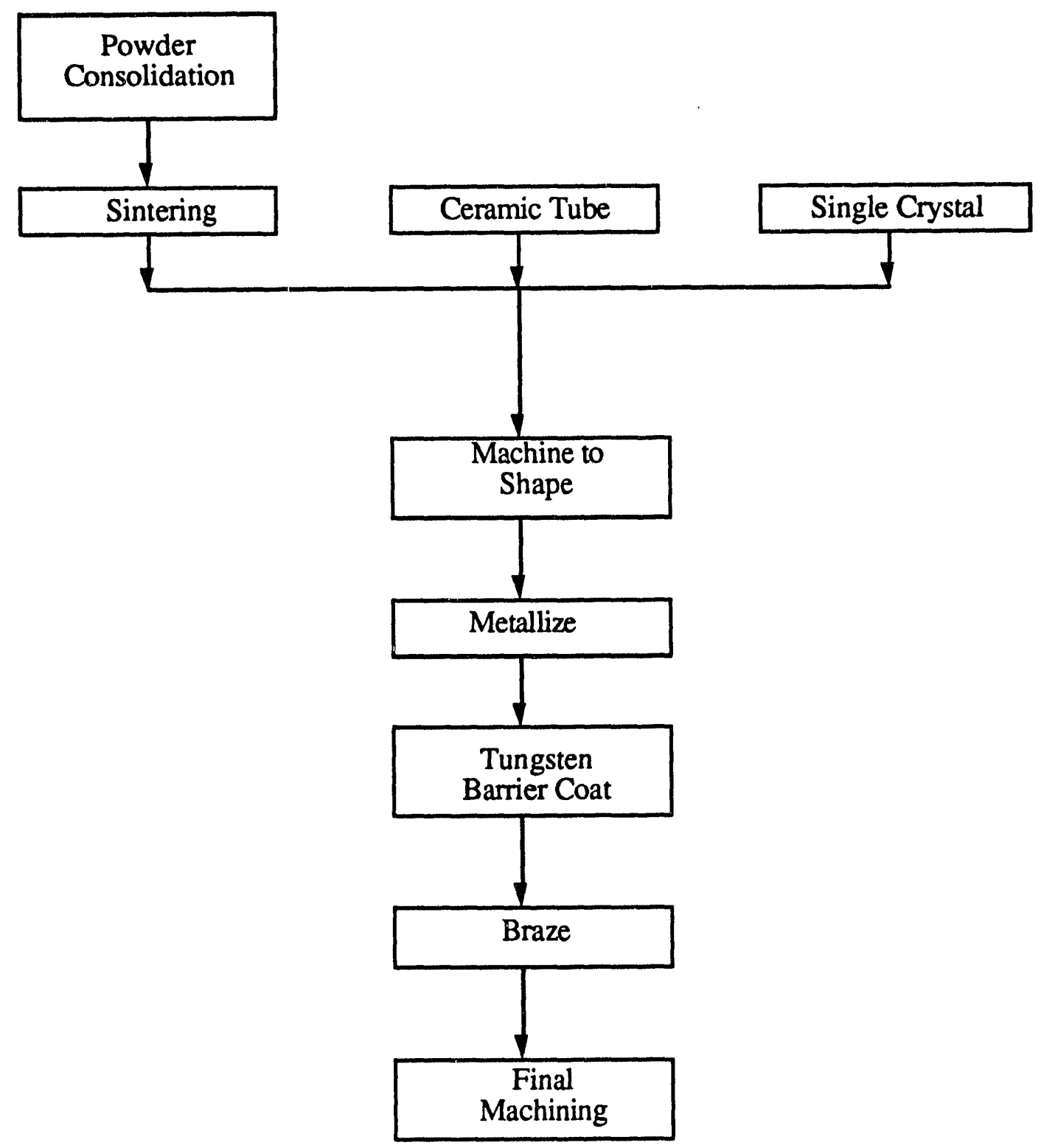

Figure 3-2. Taper Insulator Seal Fabrication Sequence 


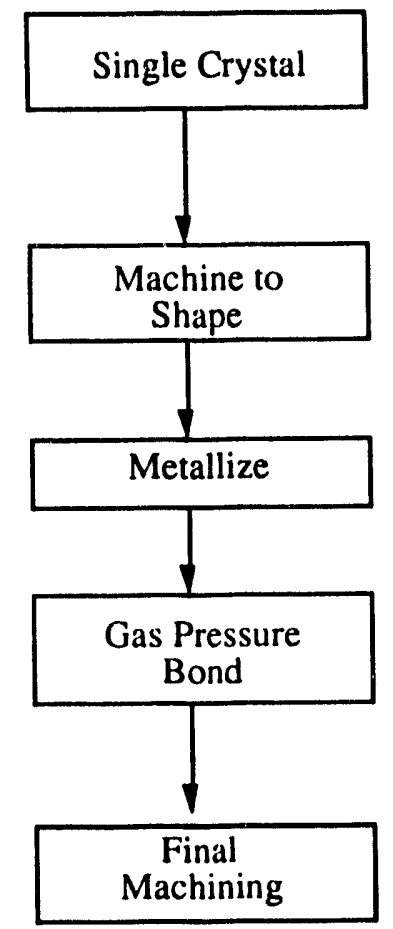

Figure 3-3. Buit Insulator Seal Fabrication Sequence

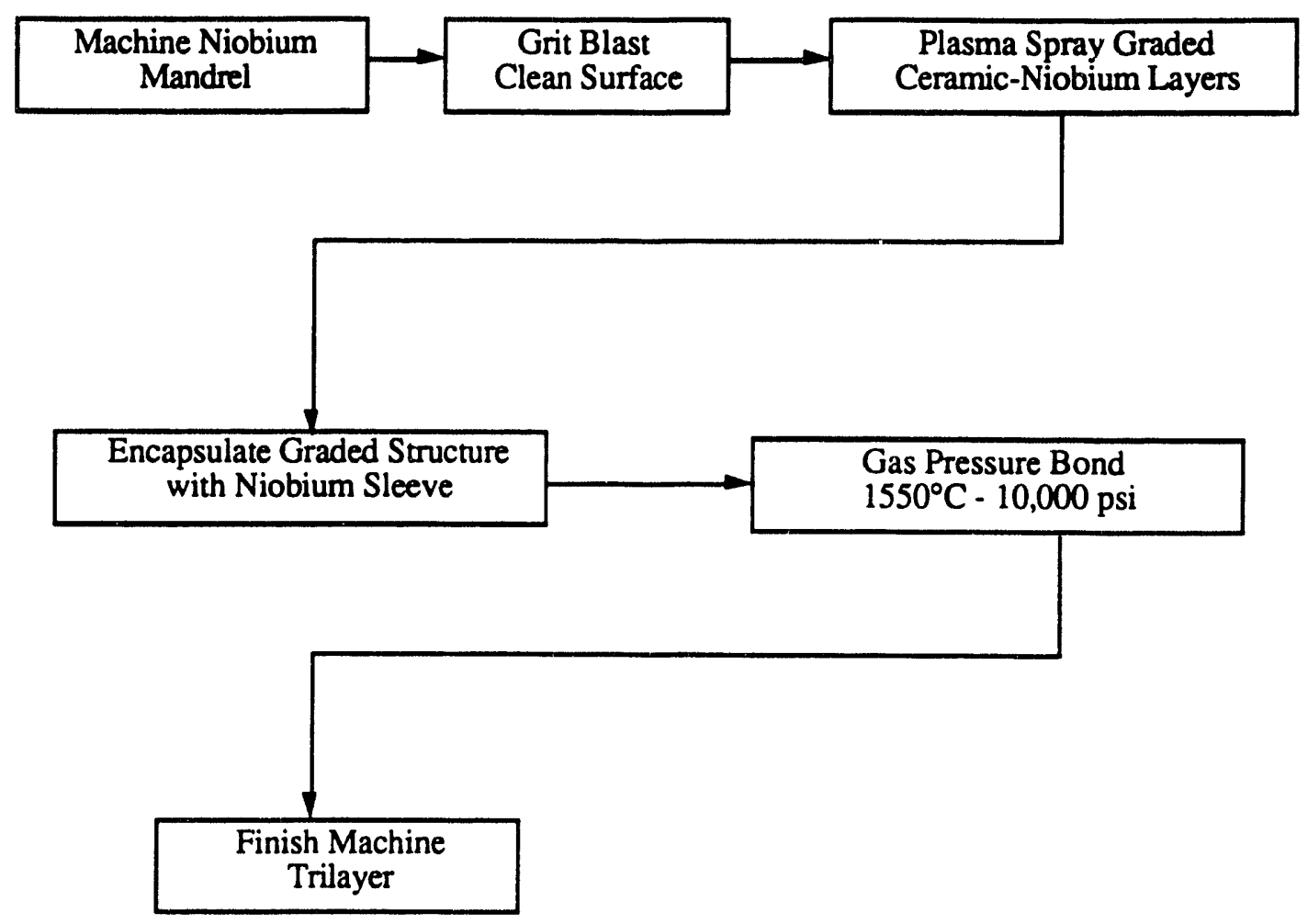

Figure 3-4. Graded Trilayer Fabrication Sequence 


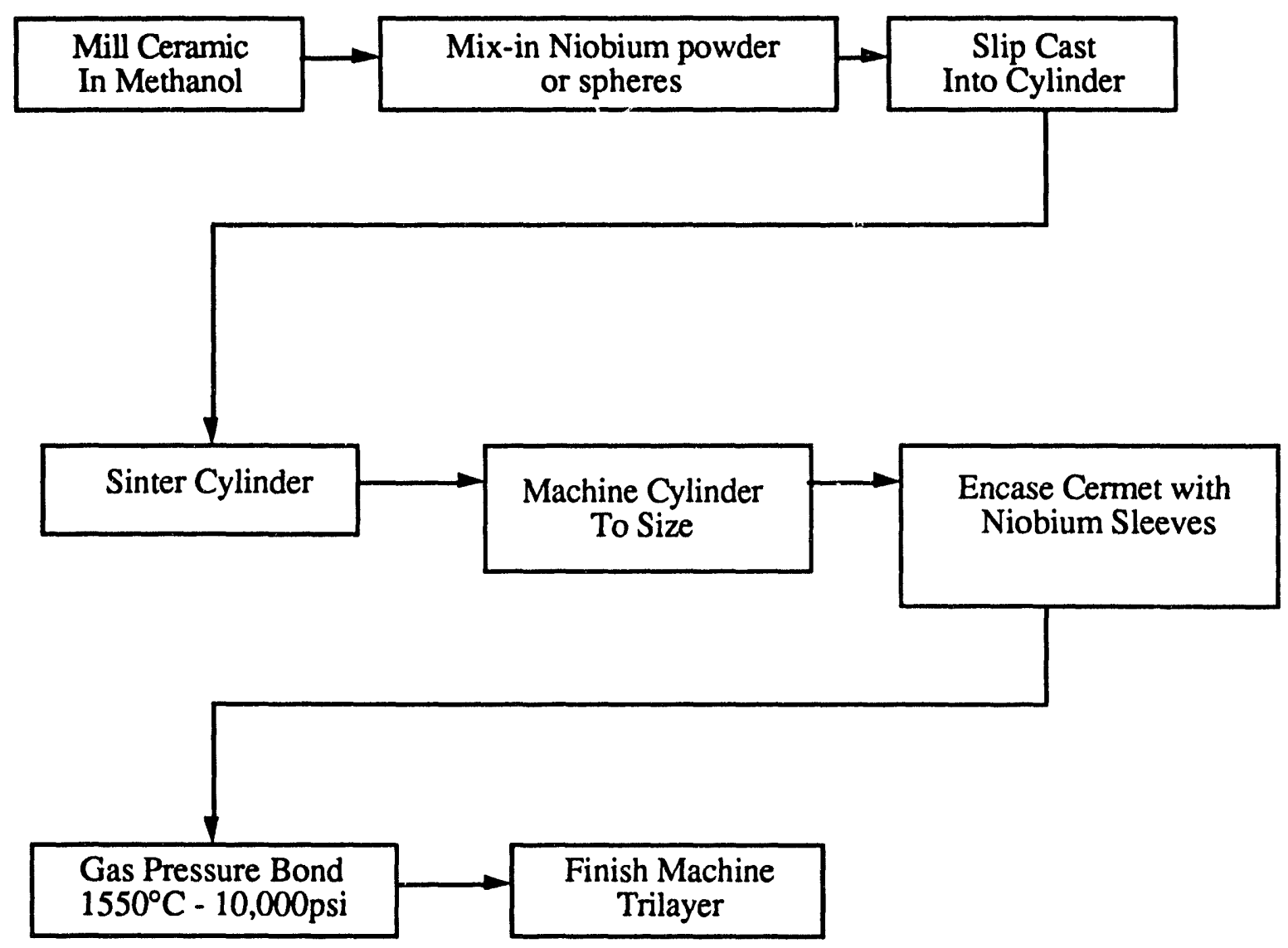

Figure 3-5. Cermet Trilayer Fabrication Sequence Developed by ThermoTrex Corporation

The cylinder is sintered and machined to a uniform thickness, e.g., $0.020 \mathrm{in}$. The cylinder is encased with niobium sleeves inside and outside and the assembly is gas pressure bonded at $1550^{\circ} \mathrm{C}$ and $10,000 \mathrm{psi}$. This bonding step densifies the cermet and bonds it to the niobium sleeves. The resulting structure is then machined to the trilayer seal configuration. The finished seal is process qualified to test seal integrity.

Addition of niobium to the ceramic to form a ceramic matrix composite has three purposes. First, addition of the metal particles increases the fracture strength of the ceramic. Second, the metal particles helps with the bond between the ceramic and the niobium sleeve. Third, the cermet better matches the coefficient of thermal expansion of niobium. Calculations have shown that about 15 volume percent niobium can be added to the ceramic matrix and still remain below the percolation threshold limit, thus minimizing the possibility of electrical shorts (Ref. 3-7). 


\subsection{Process Qualification}

All fabricated insulator seals were required to pass the following tests:

1) Leak rate check

2) Peel test (taper seals)

3) Resistance check (room temperature)

4) Thermal cycle test
$<2 \times 10^{-11} \mathrm{std} \mathrm{cc} / \mathrm{s}$

$>20 \mathrm{lb} / \mathrm{in}$.

$>1000 \mathrm{ohms}$

3 cycles from room temperature to $1473 \mathrm{~K}$ at a pressure of $<2 \times 10^{-7}$ torr.

All samples were subjected to a leak rate check, thermal cycle, and resistance check. The peel test was performed only on taper seals and only one sample from each batch was peel tested. Batches that met the process qualification were used for testing.

\subsection{Fabrication Results}

Single crystal YAG tapered rings were successfully metallized with tungsten-2\% yttria. However, in many cases, the insulator seals were not hermetic after brazing, and the seals that survived the brazing step did not remain hermetic after the final machining step. The single crystal YAG was too brittle to survive the thermal and mechanical stress associated with fabrication. Because of the difficulties in making single crystal YAG taper seals this type of seal was dropped in the early stages of the program. Polycrystalline YAG is not as brittle as the single crystal but the survival rate of finished machine insulator seals was still low.

The butt seal, although compact, was difficult to manufacture and was susceptible to bonding problems and to stress related cracking. The butt seal was also dropped early in the program.

Metallographic examination of one of the UCA-1 single crystal alumina taper seals showed that the niobium skirt had partially peeled away from the alumina at the metal ceramic interface. This appeared to result from some combination of:

1) Swelling of the alumina during irradiation.

2) Presence of fabrication induced microcracks in the insulating gap.

3) Residual stresses from the high temperature metallizing and brazing steps.

Improvements in the fabrication process were made to solve the second and third conditions. Microcracks at the insulator gap were eliminated by switching from a grinding operation to clean the gap of any remaining metallizer and braze, to a lapping operation.

Five new braze compositions, shown on Table 3-3, were identified as yielding ductile compositions in the $1250^{\circ} \mathrm{C}$ to $1750^{\circ} \mathrm{C}$ temperature range. The braze compositions were melted at the United States Bureau of Mines, Albany Research Center. Out of the five 
compositions only the titanium-vanadium and niobium-zirconium alloys were ductile enough to be rolled down to 0.002 inch thick foil. The two braze alloys were tested for wetting, bond strength and compatibility with alumina, YAG, and niobium. Taper seals were fabricated using these two alloys. The niobium-zirconium alloy was compatible with niobium, alumina and YAG while the titanium-vanadium alloy was only compatible with niobium and YAG. The survival rate for polycrystalline YAG taper seals after final machining remained low even when the lower temperature braze alloys were used.

Trilayer insulator seals made out of alumina and YAG and fabricated using the plasma spray graded method, had radial cracks across the graded structure after the gas pressure bonding step. A hermetic seal is one of the requirements of the insulator seals and the presence of cracks is detrimental. The cracking problem was solved for the alumina trilayers by using a thinner niobium spray mandrel. Changing the grading scheme and changing to a thinner niobium spray mandrel did not solve the cracking problem of the YAG trilayers. Stress analysis indicated that cracking was caused by a mismatch in the thermal expansion coefficient between the ceramic and niobium, and it occurs during the cooldown step of the gas pressure bonding cycle. Work on YAG trilayers was stopped because the cracking problem was never solved.

Trilayers made out of yttria and alumina cermets with $5 \%$ and $10 \%$ niobium did not exhibit the cracking problem.

Developmental work was performed on the fabrication of trilayers using sapphire tubes as insulator material. Examination of the tubes after gas pressure bonding indicated the presence of an unacceptable number of cracks. A batch of sapphire trilayers was fabricated with a reduced inner niobium mandrel diameter so that the outer niobium sleeve would bond first to the sapphire during processing placing the sapphire in compression. However this process step, even when coupled with the removal of surface flaws by etching with molten borax, did not solve the cracking problem. All developmental work was stopped on the sapphire trilayers.

Tále 3-3

HIGH TEMPERATURE BRAZE COMPOSITIONS AND ESTIMATED MELTING POINTS

\begin{tabular}{||l|c|}
\hline \multicolumn{1}{|c|}{ System } & Melting Point \\
\hline Titanium-Vanadium & $1606^{\circ} \mathrm{C}$ \\
Niobium-Zirconium & $1743^{\circ} \mathrm{C}$ \\
Titanium-Zirconium & $1550^{\circ} \mathrm{C}$ \\
Vanadium-Zirconium & $1267^{\circ} \mathrm{C}$ \\
Titanium-Vanadium-Zirconium & $1315^{\circ} \mathrm{C}-1425^{\circ} \mathrm{C}$ \\
\hline
\end{tabular}




\section{EX-REACTOR TEST PROGRAM}

\section{$4.1 \quad$ Objective}

The objectives of the insulator seal ex-reactor test program were to determine the electrical resistance, cesium compatibility, and hermetic behavior of the insulator seal at the operating conditions found in the H-series TFE. The ex-reactor test equipment allowed for accelerated testing of insulator seals in which the temperature, voltage, and cesium pressure exceeded the reference design conditions. The ex-reactor test equipment requirements were:
1) Temperature:
Room temperature to $1400 \mathrm{~K}$
2) Voltage: Zero to \pm 50 Volts
3) Cesium Vapor Pressure:
Zero to 50 torr.

\subsection{Test Equipment and Test Assembly}

Electrical testing of insulator seals was performed by GA.

The test stand used to measure the insulator seal electrical and hermetic properties consisted of a high temperature furnace, a liquid cesium reservoir, an ultra high vacuum pumping system, a residual gas analyzer and a cesium detector. A schematic of the test stand is shown in Fig. 4-1. A schematic of the insulator seal test assembly with a trilayer insulator seal is shown in Fig. 4-2. The electrical resistance of the insulator seal was measured with a Keithley 617 programmable electrometer. Seal integrity was determined by monitoring the leakage of helium or cesium through the insulator seal to the vacuum chamber.

\subsection{Test Procedure}

All insulator seals were short term electrically tested with a 1 volt applied potential under the following heating and cooling conditions:

1) Room temperature to $900 \mathrm{~K}$ in 1 hour.

2) $900 \mathrm{~K}$ to $1400 \mathrm{~K}$ at $100^{\circ} / \mathrm{hr}$.

3) $1400 \mathrm{~K}$ to $900 \mathrm{~K}$ at $100 \% \mathrm{hr}$.

4) Thermal cycle three times from $900 \mathrm{~K}$ to $1400 \mathrm{~K}$ at $500^{\circ} / \mathrm{hr}$. and back to $900 \mathrm{~K}$ at $500 \%$ hr.

5) $900 \mathrm{~K}$ to $1400 \mathrm{~K}$ at $100^{\circ} / \mathrm{hr}$.

6) $1400 \mathrm{~K}$ to $900 \mathrm{~K}$ at $100 \% \mathrm{hr}$.

7) $900 \mathrm{~K}$ to room temperature.

The rationale for the short term testing was to determine the initial electrical and hermetic properties of the insulator seal. Measuring the electrical properties from 900 to $1400 \mathrm{~K}$ before and after thermal cycling permitted determination of the activation energy for 


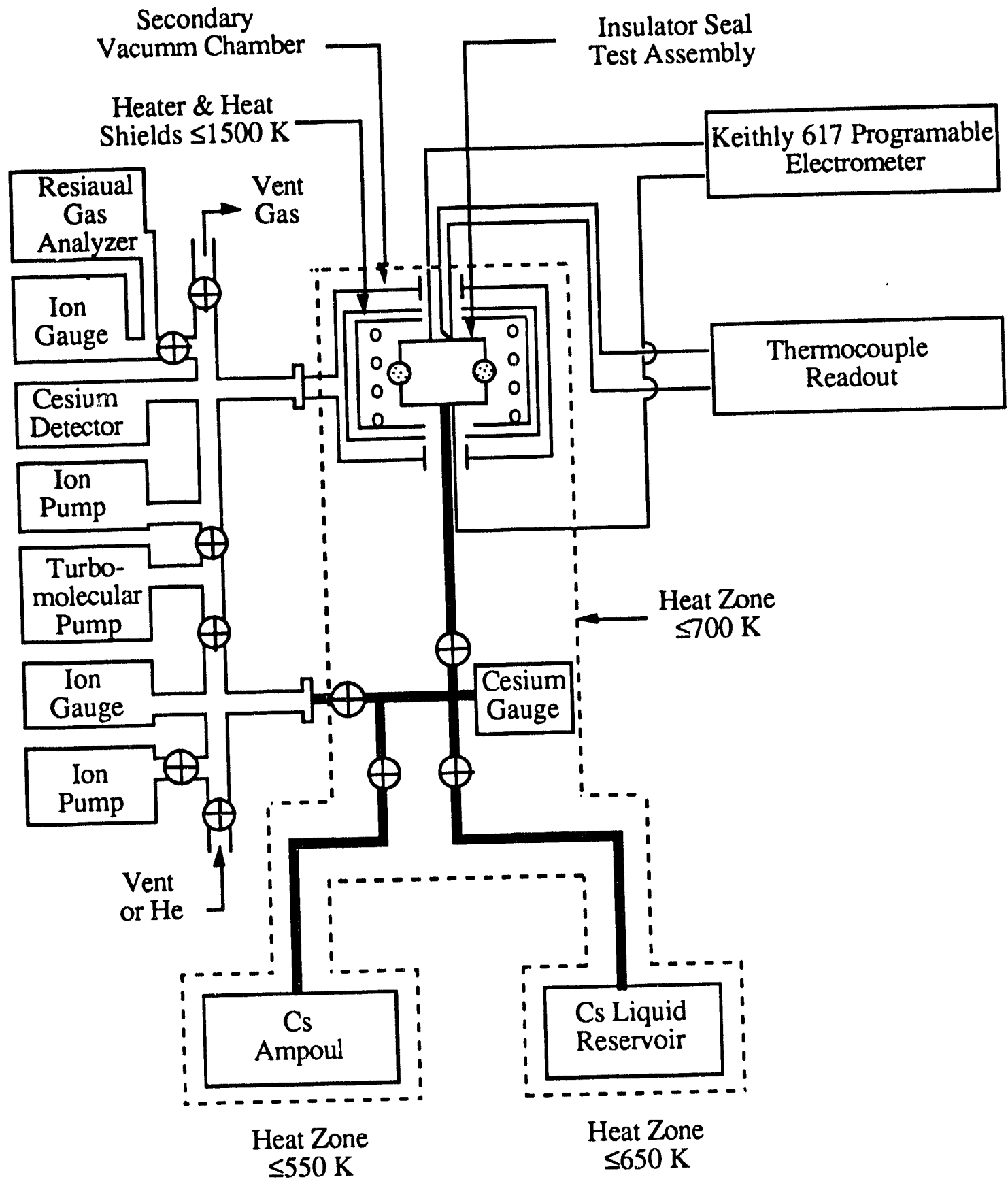

Figure 4-1. Schematic Insulator Seal Ex-Reactor Test Stand 


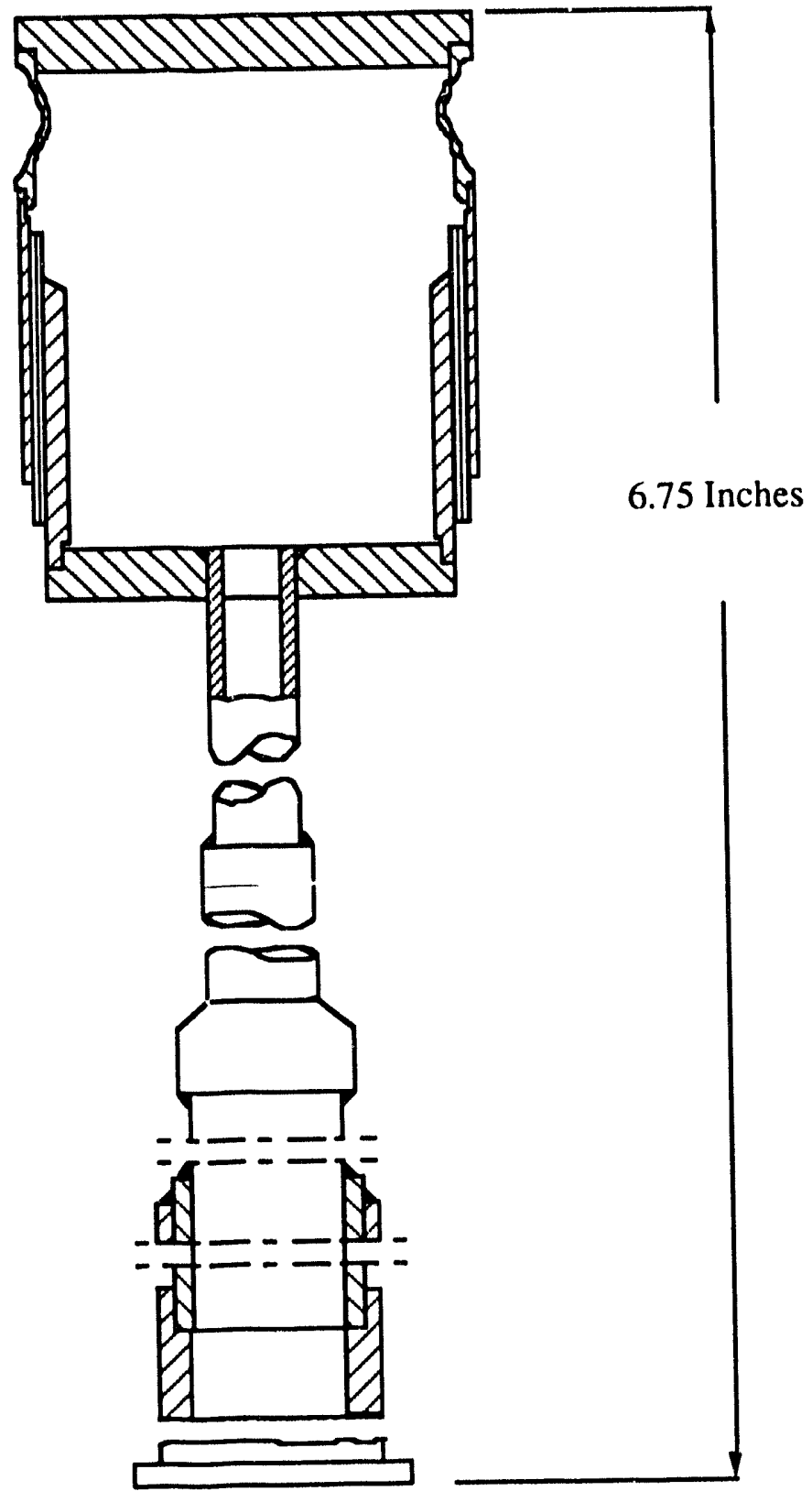

Figure 4-2. Insulator Seal Test Assembly With Trilayer Insulator Seal 
electrical conductivity. Changes in activation energy with time would indicate a deterioration of the electrical properties of the material. The activation energy was also used to determine the conditions needed to perform any subsequent accelerated testing. The hermetic condition of the seal was determined from the He leak tightness after temperature cycling between $900 \mathrm{~K}$ and $1400 \mathrm{~K}$.

A justification for accelerated testing required the consideration of a simple model for the ionic conductivity of the insulator seal. The electrolytic stability can be modeled by considering the number of ions transported out of the insulator:

$$
N=\sigma_{i} V A t / L q
$$

where $\mathbf{N}=$ number of ions,

$$
\begin{aligned}
& \sigma_{i}=\text { ionic conductivity, } \\
& \mathrm{V}=\text { applied voltage, } \\
& \mathrm{A}=\text { cross sectional area of insulator, } \\
& \mathrm{t}=\text { time, } \\
& \mathrm{L}=\text { thickness of insulator, } \\
& \mathrm{q}=\text { charge of an ion, }
\end{aligned}
$$

and $\quad \sigma_{i}=n_{i} q \mu_{i}$,

where $\mathrm{n}_{\mathrm{i}}=$ ionic concentration,

$$
\mu_{\mathrm{i}}=\text { ionic mobility. }
$$

If ion transport for a set of conditions is to be accelerated in time, then a higher temperature and/or voltage must be used. If the reference temperature is $T_{1}$, an accelerated temperature $\mathrm{T}_{2}$ can be determined by equating the number of ions to be transported out of an insulator at temperatures $T_{1}$ and $T_{2}$, specifically

$$
\begin{gathered}
\mu_{i}\left(T_{1}\right) V_{1} t_{1}=\mu_{i}\left(T_{2}\right) V_{2} t_{2} \\
\mu_{i}=\mu_{0} \exp -\Delta E_{0} / k T
\end{gathered}
$$

then

$$
\exp \left(-\Delta E_{0} / k T_{1}\right) V_{1} t_{1}=\exp \left(-\Delta E_{o} / k T_{2}\right) V_{2} t_{2}
$$

where $\Delta E_{0}$ is the ionic activation energy determined experimentally. 
Assume the reference conditions are:

$$
\begin{aligned}
& T_{1}=1150 \mathrm{~K} \\
& V_{1}=0.5 \text { volt } \\
& t_{1}=61,320 \text { hours (7 years). }
\end{aligned}
$$

For an accelerated test with $V_{2}=1$ volt and $t_{2}=504$ hours, equation 5 can be solved to determine the required acceleration temperature. Aluminum oxide with an activation energy $\left(\Delta \mathrm{E}_{\mathrm{o}}\right)$ of $3.5 \mathrm{eV}$ (Ref. 4-1) requires that the accelerated testing be done at $1302 \mathrm{~K}$.

\subsection{Test Results}

\subsubsection{Taper Insulator Seals}

A single crystal alumina taper seal was tested for a total of 200 days at the accelerated temperature of $1273 \mathrm{~K}$ and at three different potentials: 1,10 and 30 volts. The resistance as a function of time, shown in Fig. 4-3, shows no deterioration with applied potential and temperature. These accelerated conditions translate to a lifetime equivalent time of 159 years at the reference conditions of 0.5 volts and $1170 \mathrm{~K}$ respectively. While 159 years is not a realistic life expectancy, it can be concluded that there are no failure mechanisms apparent under the test conditions. The activation energy for conduction calculated from the initial short term test was $2.7 \mathrm{eV}$. The seal was not exposed to cesium vapor during electrical testing because the test assembly was not hermetic.

\subsubsection{Trilayer Insulator Seals}

The design of the trilayer seal (Fig. 3-1) is different from that of the sheath insulator (Fig. 2-1), but the trilayer seal fabrication technology is identical to that of the sheath insulator. Ex-reactor tests of the sheath insulator can be used to estimate the performance of the trilayer seal. Graded and niobium cermet sheath insulators were tested at RAI under nominal and accelerated conditions. The tests were performed with guarded electrodes thus eliminating any surface conduction artifacts.

Measurements of the electrical characteristics of yttria sheath insulators both graded and cermet have shown resistance values ranging form $10^{5} \mathrm{ohms}$ at $1100 \mathrm{~K}$ to unstable conditions characterized by rapid degradation and electrical shorting. The initial poor performance of the yttria sheath insulators was traced to carbon impurities present in the purchased ceramic powders. The carbon was usually present as small particles or inclusions in agglomerates of yttria.

Yttria sheath insulators were also fabricated from starting powders which had a low carbon content $(<100 \mathrm{ppm})$. The electrical behavior of this high purity test samples improved over the high carbon content samples but the samples were still shorting during the accelerated testing at the higher temperatures and voltages. At the higher temperatures and 


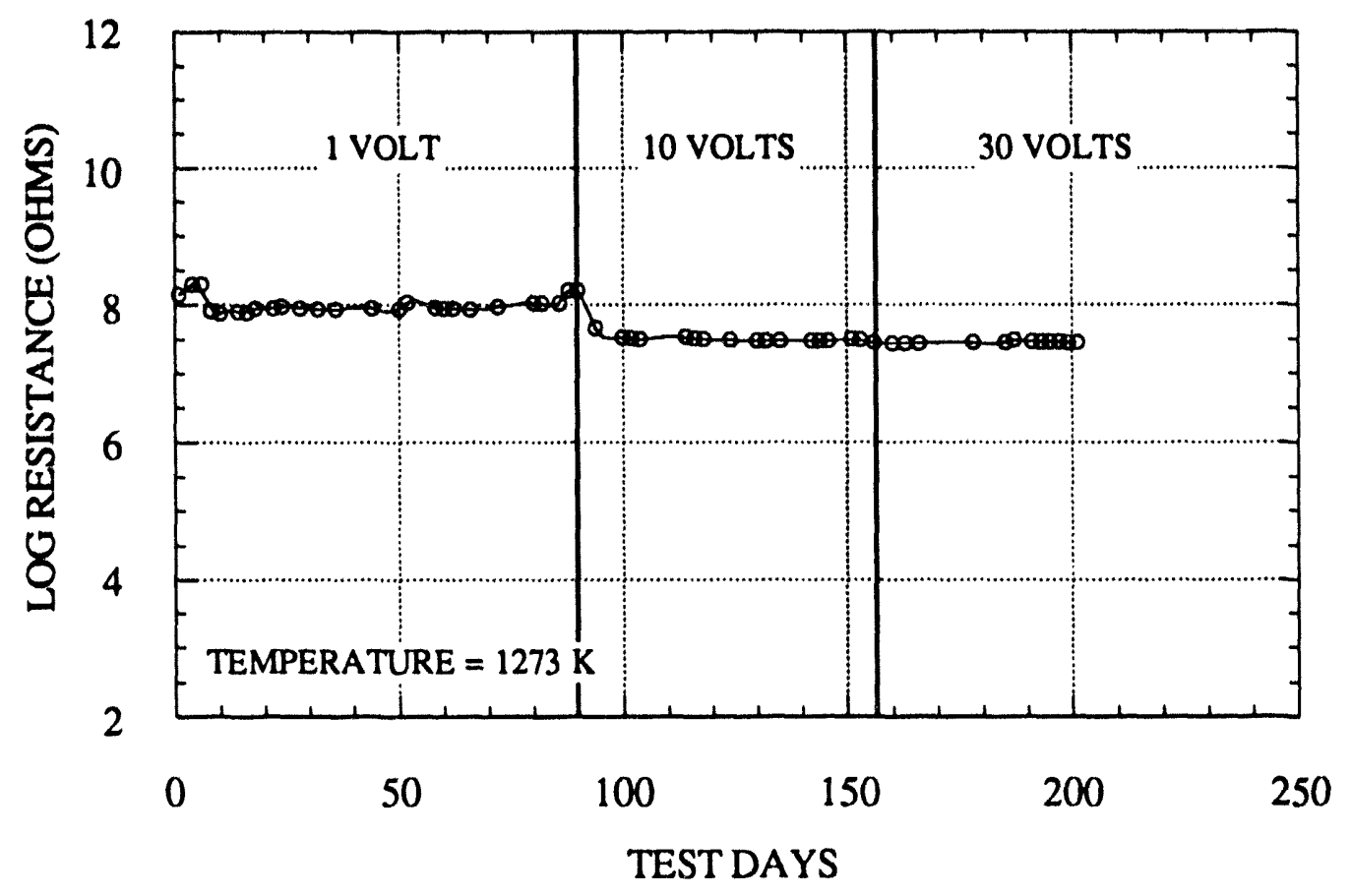

Figure 4-3. Single Crystal Alumina Taper Seal Resistance vs Time

voltages the ionic conductivity is dominating the conduction process and the insulator was failing by electrolytic degradation. The literature (Ref. 3-4) indicates that doping alumina with donors reduces the ionic conductivity of the alumina by many orders of magnitude. Yttria sheath insulators were fabricated with additions of $\mathrm{CeO}_{2}$ and $\mathrm{ZrO}_{2}$ to act as donors in the yttria ionic structure and reduce the ionic conductivity. Doping did not significantly improve the electrical characteristics of yttria, and yttria was finally dropped as an insulator material for sheath insulators. Table 4-1 summarizes the yttria sheath insulators ex-reactor testing.

YAG sheath insulators had a resistance between $10^{3}$ and $10^{4} \mathrm{ohms}$ at $1100 \mathrm{~K}$. These were better than for the yttria samples but they did not compare with alumina which were three to four orders of magnitude higher. YAG was dropped from the list of insulator materials for sheath insulators primarily because of fabrication problems. YAG sheath insulators could not be fabricated without cracks. Cracking is a problem when the intended use is as a trilayer seal where leak tightness is a requirement. Also, heat transfer from the collector to the reactor liquid metal coolant can be adversely affected and affect the thermionic performance of the converter. As will be shown in the next section, in-reactor testing of alumina sheath insulators was very encoraging. Swelling of alumina was not a problem when the correct end configuration was used. Alumina became the reference material and the necessity to develop YAG decreased as a result. Table 4-2 summarizes the YAG sheath insulators ex-reactor testing. 
Table 4-1

YTTRIA SHEATH INSULATORS EX-REACTOR TESTING

\begin{tabular}{||c|l|c|c|c|c|c|}
\hline $\begin{array}{c}\text { Number of } \\
\text { Samples } \\
\text { Tested }\end{array}$ & $\begin{array}{c}\text { Fabrication } \\
\text { Process }\end{array}$ & $\begin{array}{c}\text { Temperature } \\
\text { Range (K) }\end{array}$ & $\begin{array}{c}\text { Voltage } \\
\text { (Volts) }\end{array}$ & $\begin{array}{c}\text { Duration } \\
\text { of Test } \\
\text { (Hours) }\end{array}$ & $\begin{array}{c}\text { End of Test } \\
\text { Resistance } \\
(~\end{array}$ & Test Results \\
\hline 10 & Graded & $995-1270$ & $7.5 \& 10$ & $16-838$ & 100 & $\begin{array}{l}\text { Failed due to } \\
\text { low resistance } \\
\text { from carbon } \\
\text { contamination }\end{array}$ \\
11 & Graded & $1050-1250$ & $7.5 \& 30$ & $312-3696$ & $\begin{array}{l}\text { Typical: }<100 \\
\text { Some: }<3000\end{array}$ & $\begin{array}{l}\text { Most failed due } \\
\text { to low } \\
\text { resistance } \\
\text { Failed due to }\end{array}$ \\
6 & Slip Cast & 1250 & 7.5 & $1253-2496$ & $<100$ & $\begin{array}{l}\text { low resistance } \\
\text { Failed due to } \\
\text { low resistance }\end{array}$ \\
\hline & $\begin{array}{l}\text { Slip Cast } \\
10 \% \mathrm{Nb} \\
\text { Cermet }\end{array}$ & 1074 & 7.5 & $<100$ & $<100$ \\
\hline
\end{tabular}

Table 4-2

YAG SHEATH INSULATORS EX-REACTOR TESTING

\begin{tabular}{||c|c|c|c|c|c|c||}
\hline $\begin{array}{c}\text { Number of } \\
\text { Samples } \\
\text { Tested }\end{array}$ & $\begin{array}{c}\text { Fabrication } \\
\text { Process }\end{array}$ & $\begin{array}{c}\text { Temperature } \\
\text { Range (K) }\end{array}$ & $\begin{array}{c}\text { Voltage } \\
\text { (Volts) }\end{array}$ & $\begin{array}{c}\text { Duration } \\
\text { of Test } \\
\text { (Hours) }\end{array}$ & $\begin{array}{c}\text { End of Test } \\
\text { Resistance } \\
(\quad)\end{array}$ & Test Results \\
\hline 4 & Graded & $1020-1120$ & 10 & $24-6931$ & $2000-11000$ & $\begin{array}{l}\text { Marginal resistance } \\
\text { One sample was used } \\
\text { in UCA-2 } \\
1\end{array}$ \\
\hline Slip cast & 1090 & 7.5 & 1100 & 2100 & Marginal resistance \\
\hline
\end{tabular}

Alumina sheath insulators both graded and cermet had excellent electrical characteristics. Samples were tested to voltages thirteen times higher than nominal and 200 degrees higher than nominal with no indications of electrical degradation and no changes in the activation energy. A graded alumina and an alumina $5 \%-\mathrm{Nb}$ cermet sheath insulator were tested for 377 days at the accelerated conditons of 100 volts and $1270 \mathrm{~K}$. The resistivity as a function of time, temperature, and voltage for these two sheath insulators are shown in Fig. 4-4. 


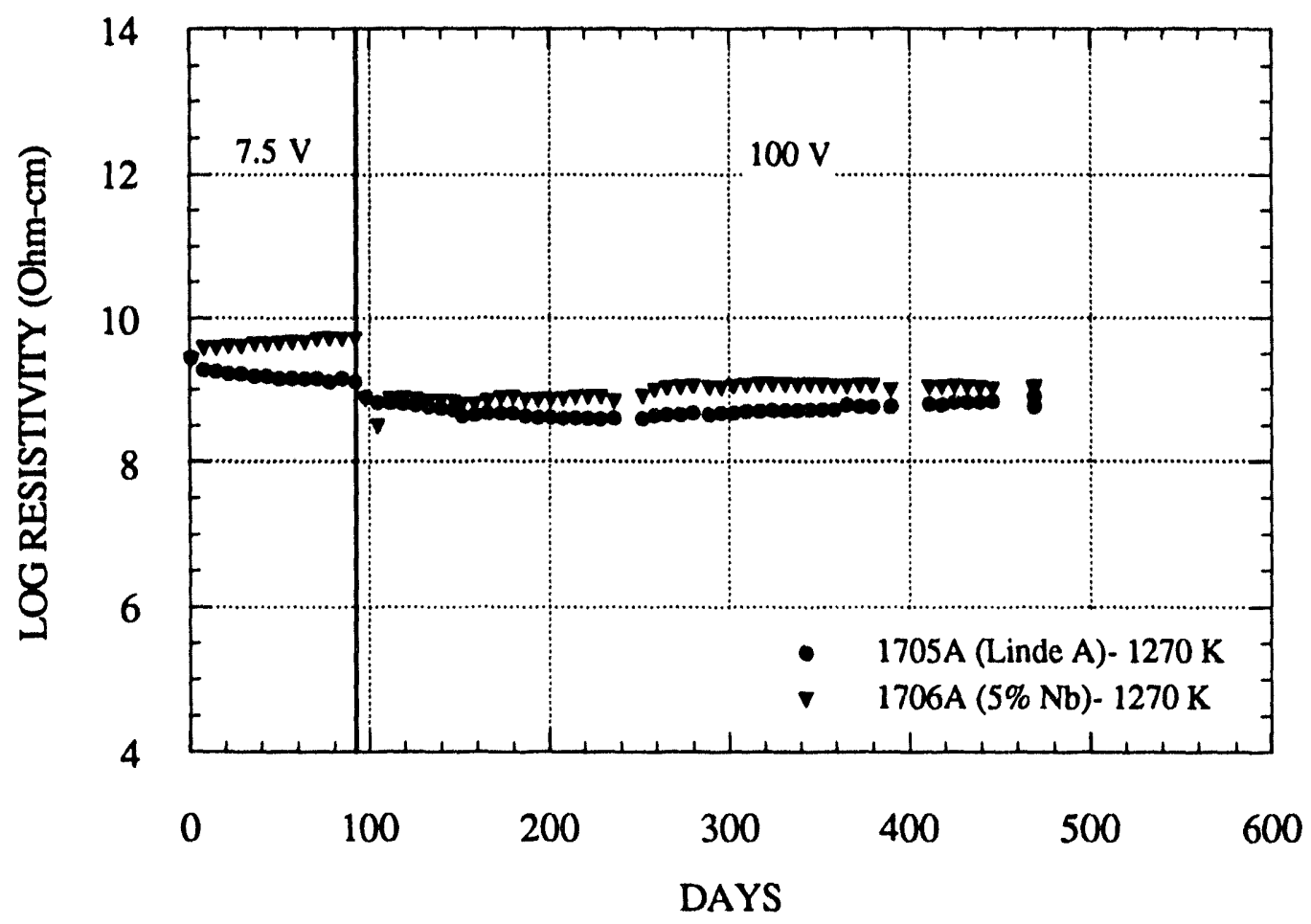

Figure 4-4. Electrical Resistivity vs Time for Graded Alumina and Alumina Cermet $(5 \%-\mathrm{Nb})$ Sheath Insulators

Cermet alumina sheath insulators with a niobium content greater than $5 \%$ were also tested as part of the sheath insulator test program. Sheath insulators with $10 \%$ niobium were tested at nominal and accelerated conditions (Fig. 4-5). At the nominal conditions of 7.5 volts and nominal $1070 \mathrm{~K}$ and accelerated temperatures of $1170 \mathrm{~K}$ and $1270 \mathrm{~K}$ the resistance with time was constant with no indication of electrical degradation. Increasing the applied voltage to an accelerated condition of 100 volts resulted in failure from electrical breakdown. An examination of the microstructure of this cermet showed that the mean distance between niobium particles was only about $20 \mu \mathrm{m}$. The electric field associated with this dimension is $5 \times 10^{4} \mathrm{~V} / \mathrm{cm}$. The literature (Ref.3-8) reports an electrical breakdown field for alumina between $3 \times 10^{4}$ to $2 \times 10^{5} \mathrm{~V} / \mathrm{cm}$ at $1150 \mathrm{~K}$. Cermets with niobium contents equal to or less than $10 \%$ are good insulators for sheath insulators for the TFE-VP, but accelerated testing must be limited to voltages that do not exceed the electrical breakdown field for alumina. Table 4-3 summarizes the alumina sheath insulators ex-reactor testing.

A 5\% niobium cermet trilayer insulator seal from the same batch of seals fabricated for the UCA-3 in-reactor test was tested for 82 days at $1273 \mathrm{~K}$ and 1 volt with no cesium. The resistance of the seal remained constant at $7 \times 10^{6}$ ohms. The activation energy for conduction obtained from the test was $3.15 \mathrm{eV}$. 


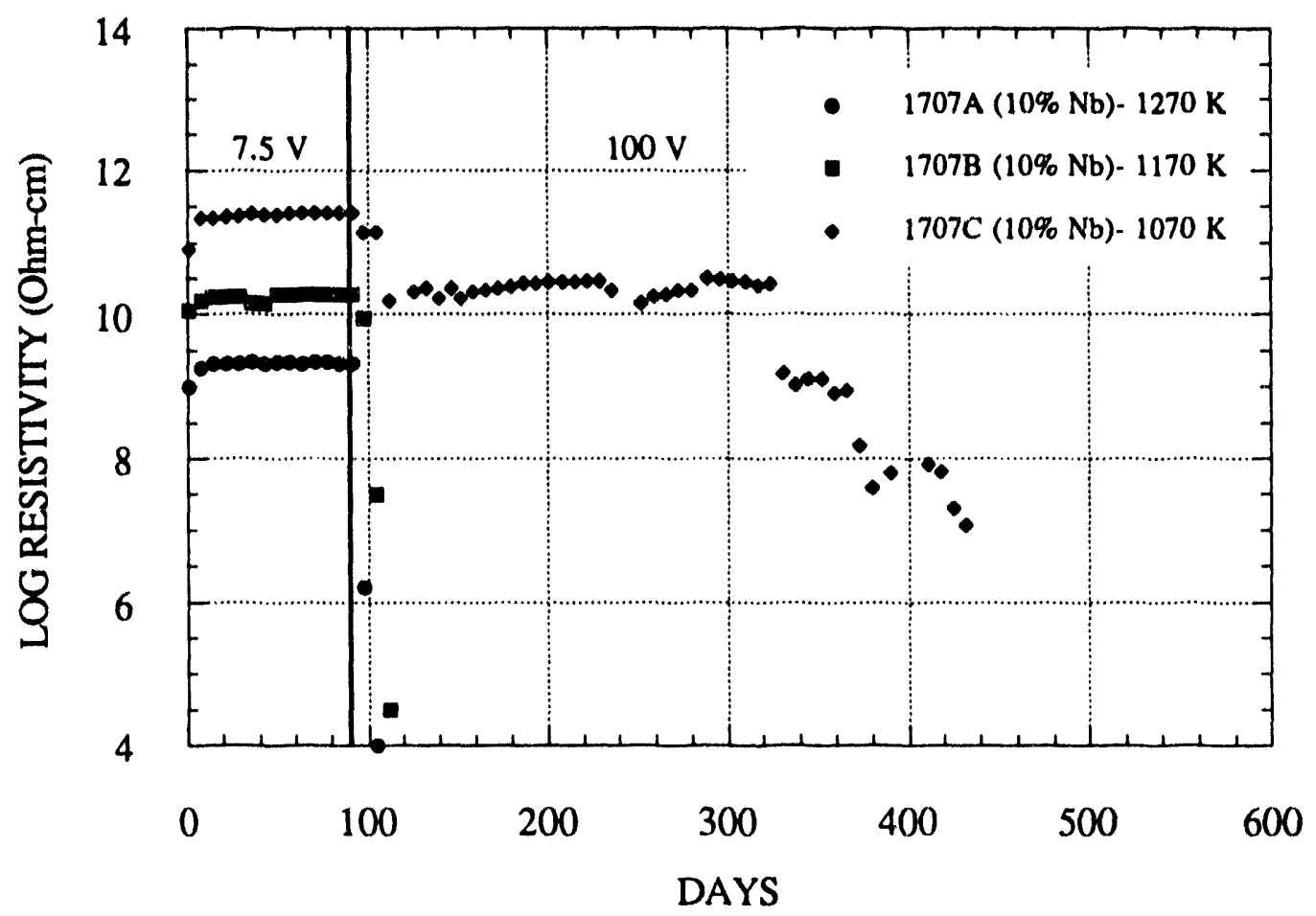

Figure 4-5. Electrical Resistivity vs Time for Alumina Cermet (10\%-Nb) Sheath Insulators

Table 4-3

ALUMINA SHEATH INSULATORS EX-REACTOR TESTING

\begin{tabular}{|c|c|c|c|c|c|c|}
\hline $\begin{array}{l}\text { Number of } \\
\text { Samples } \\
\text { Tested }\end{array}$ & $\begin{array}{c}\text { Fabrication } \\
\text { Process }\end{array}$ & $\begin{array}{l}\text { Temperature } \\
\text { Range (K) }\end{array}$ & $\begin{array}{l}\text { Voltage } \\
\text { (Volts) }\end{array}$ & $\begin{array}{c}\text { Duration } \\
\text { of Test } \\
\text { (Hours) }\end{array}$ & $\begin{array}{l}\text { End of Test } \\
\text { Resistance } \\
(\text { ) }\end{array}$ & Test Results \\
\hline 31 & Graded & $1070-1270$ & $\begin{array}{l}7.5,10 \\
30,50 \\
\& 100\end{array}$ & $24-9048$ & $>10^{7}$ & Results good \\
\hline 2 & $\begin{array}{l}\text { Slip cast } \\
15 \% \mathrm{Nb} \\
\text { cermet }\end{array}$ & $1100-1130$ & 7.5 & $24-150$ & $<100$ & $\begin{array}{l}\text { Failed due to low } \\
\text { resistance }\end{array}$ \\
\hline 30 & $\begin{array}{l}\text { Slip cast } \\
10 \% \mathrm{Nb} \\
\text { cermet }\end{array}$ & $1070-1300$ & $\begin{array}{l}7.5,10 \\
\& 100\end{array}$ & $1-8160$ & $\begin{array}{l}<100 \\
>10^{5}\end{array}$ & $\begin{array}{l}\text { Some failed due to low } \\
\text { resistance. Some failed } \\
\text { due to electrical break- } \\
\text { down at high voltages. } \\
\text { Some results were good. }\end{array}$ \\
\hline 20 & $\begin{array}{l}\text { Slip cast } \\
5 \% \mathrm{Nb} \\
\text { cermet }\end{array}$ & $1070-1300$ & $\begin{array}{l}7.5,10 \\
30,50 \\
\& 100\end{array}$ & $72-9048$ & $>10^{5}$ & Results good \\
\hline 2 & Sapphire & 1250 & 7.5 & 750 & $>10^{6}$ & Results good \\
\hline
\end{tabular}


A $10 \%$ niobium cermet trilayer insulator seal, also from the UCA-3 in-reactor test batch, was selected to test for cesium compatibility. The trilayer seal was first tested for 60 days at $1273 \mathrm{~K}$ with no cesium. The first 30 days of testing were at an applied potential of 1 volt and the remaining 30 days were at an applied potential of 10 volts. The resistance at $1273 \mathrm{~K}$ at the end of the 60 days of testing was $2.0 \times 10^{6} \mathrm{ohms}$ The activation energy for electrical conduction at the start and end of the test was constant at $2.7 \mathrm{eV}$ in the temperature range $970 \mathrm{~K}$ to $1420 \mathrm{~K}$.

Before any cesium was introduced into the cesium side of the insulator seal, the seal temperature was lowered to $1150 \mathrm{~K}$ still keeping the same applied potential of 10 volts. The temperature of the liquid cesium reservoir was slowly increased. At a liquid cesium reservoir temperature of $130^{\circ} \mathrm{C}$, that corresponds to a cesium pressure of $3 \times 10^{3}$ torr, the resistance of the seal had dropped to $5 \times 10^{3} \mathrm{ohms}$. At a liquid reservoir temperature $135^{\circ} \mathrm{C}$ $\left(3.8 \times 10^{-3}\right.$ torr) the Keithley electrometer exceeded its current limit of $2 \mathrm{~mA}$. The applied potential was decreased to 1 volt to reduce the current. At a cesium pressure of 0.0214 torr $\left(170^{\circ} \mathrm{C}\right.$ liquid reservoir temperature) the resistance had dropped to $870 \mathrm{ohms}$. As the liquid cesium reservoir temperature was increased from $170^{\circ} \mathrm{C}$ to $320^{\circ} \mathrm{C}$ ( 3 torr), the resistance increased and leveled off at a value of $2 \times 10^{3}$ ohms. This behavior was reversible and reproducible. Surface conduction and vapor conduction across the narrow insulating region in the trilayer seal was being enhanced by the presence of the cesium vapor and the closeness of the niobium particles in the $10 \%$ cermet. Testing was stopped because surface electrical properties rather than bulk electrical properties were being measured. For application as an insulator seal, the cermet trilayer seal design needs to be modified and the niobium content of the cermet decreased to maximize the surface insulating path and reduce surface effects that are controlling the sample resistance. 


\section{IN-REACTOR TEST PROGRAM}

\subsection{Objective}

The objectives of the in-reactor test program were to determine the material stability, electrical resistance and hermetic integrity of the insulator seal under fast neutron irradiation.

\subsection{Requirements}

The in-reactor test program had four requirements:

1) Irradiate the insulator seals to a nominal fast neutron fluence $(\mathrm{E}>0.1 \mathrm{MeV})$ of $2.7 \times 10^{22} \mathrm{n} / \mathrm{cm}^{2}$ at a temperature of $1150 \mathrm{~K}$.

2) Measure the electrical resistance of the insulator seal after irradiation up to a temperature of $1150 \mathrm{~K}$.

3) Measure the helium (He) leak rate of the insulator seal after irradiation.

4) Perform metallographical examination of selected insulator seals after irradiation.

\subsection{Test Description}

The UCA-1,-2,-3, and UFAC-3 were a series of accelerated insulator seal tests performed in fast neutron spectrum reactors. The UCA-1, and -2 testing took place in FFTF at WHC. The UCA-3 and UFAC-3 testing took place in EBR-II at ANL-W. The tests were conducted in the MOTA for FFTF and in the standard B-7A capsule for EBR-II.

Temperature control was achieved by means of gamma heaters and/c. $\mathrm{He} / \mathrm{Ar}$ gas mixtures.

The first of the tests, UCA-1, was irradiated in FFTF Cycle 9. Irradiation testing began on September 11, 1986 and ended in October 10, 1987. The irradiation lasted 341.1 effective full power days (EFPD). The accumulated fast fluence (neutron energy $>0.1 \mathrm{MeV}$ ) was between $2.5 \times 10^{22} \mathrm{n} / \mathrm{cm}^{2}$ and $7.2 \times 10^{22} \mathrm{n} / \mathrm{cm}^{2}$.

UCA-2 was the second in the series of in-reactor component testing. Irradiation started in Cycle 10 of the FFTF which began on November 24, 1987 and ended January 9, 1989 , with a total of 355 EFPD. End of test fluences ranged from $3.6 \times 10^{22} \mathrm{n} / \mathrm{cm}^{2}$ to $6.5 \times 10^{22} \mathrm{n} / \mathrm{cm}^{2}$.

The third test in the series was irradiated as an add-on to the third Uninstrumented Fueled Accelerated Component test assembly (UFAC-3). Irradiation started in Cycle 153 of EBR-II which began on January 28, 1990 and ended September 21, 1990. The samples were exposed for 170 EFPDs to a fast fluence between $2.4 \times 10^{22} \mathrm{n} / \mathrm{cm}^{2}$ and $2.8 \times 10^{22} \mathrm{n} / \mathrm{cm}^{2}$. In 
addition to testing complete insulator seals, the individual components used to make the seal were tested.

UCA-3, was the last in the series of in-reactor component tests. It incorporated results from ex-reactor testing as well as results from the postirradiation examination of UCA-1 and UCA-2 insulator seals. UCA-3 consisted of two batches, A and B. Irradiation for Batch A started in Cycle 156 of EBR-II on December 20, 1990 and ended April 1991 with an estimated exposure of 95 EFPDs and a fast fluence of approximately $1.5 \times 10^{22} \mathrm{n} / \mathrm{cm}^{2}$. Batch B started irradiation in Cycle 157 of EBR-II. Irradiation was completed with the end of Run 158 January 19, 1992. The Batch B capsule accumulated 110.1 EFPDs of irradiation with an estimated total fast fluence of $1.8 \times 10^{22} \mathrm{n} / \mathrm{cm}^{2}$. Batch $B$ also included individual insulator seal components.

The insulator seal in-reactor test matrix is shown in Table 5-1.

Table 5-1

INSULATOR SEAL IN-REACTOR TEST MATRIX

\begin{tabular}{|c|c|c|c|c|}
\hline Test & $\begin{array}{l}\text { Test Specimen } \\
\text { Identification }\end{array}$ & Design & Number & Material \\
\hline UCA-1 & $\begin{array}{l}\mathrm{L}-1,-2,-3 \\
\mathrm{~B}-1,-2,-3 \\
\mathrm{~T}-1,-2,-3\end{array}$ & $\begin{array}{l}\text { Taper } \\
\text { Butt } \\
\text { Trilayer }\end{array}$ & $\begin{array}{l}3 \\
3 \\
3\end{array}$ & $\begin{array}{l}\text { Single crystal } \mathrm{Al}_{2} \mathrm{O}_{3} \\
\text { Single crystal } \mathrm{Al}_{2} \mathrm{O}_{3} \\
\text { Graded } \mathrm{Y}_{2} \mathrm{O}_{3}\end{array}$ \\
\hline UCA-2 & $\begin{array}{l}003 \\
001 \\
297 \mathrm{~B}, 280 \mathrm{~B}\end{array}$ & $\begin{array}{l}\text { Taper } \\
\text { Taper } \\
\text { Trilayer }\end{array}$ & $\begin{array}{l}1 \\
1 \\
2\end{array}$ & $\begin{array}{l}\text { Single crystal } \mathrm{Al}_{2} \mathrm{O}_{3} \\
\text { Single crystal } \mathrm{YAG} \\
\text { Graded } \mathrm{Y}_{2} \mathrm{O}_{3}\end{array}$ \\
\hline UFAC-3 & $\begin{array}{l}\text { A-III } \\
\text { YAG-I, -II, -III }\end{array}$ & $\begin{array}{l}\text { Taper } \\
\text { Taper }\end{array}$ & $\begin{array}{l}1 \\
3\end{array}$ & $\begin{array}{l}\text { Single crystal } \mathrm{Al}_{2} \mathrm{O}_{3} \\
\text { Polycrystalline } \mathrm{YAG}\end{array}$ \\
\hline UCA-3 Batch A & SC-1, -2 & Taper & 2 & Single crystal $\mathrm{Al}_{2} \mathrm{O}_{3}$ \\
\hline UCA-3 Batch B & $\begin{array}{l}\text { SC-3, } 1439 \\
\text { T-NbV-1 } \\
1616,1617 \\
1620,1621 \\
1623,1629\end{array}$ & $\begin{array}{l}\text { Taper } \\
\text { Taper } \\
\text { Trilayer } \\
\text { Trilayer } \\
\text { Trilayer }\end{array}$ & $\begin{array}{l}2 \\
1 \\
2 \\
2 \\
2\end{array}$ & $\begin{array}{l}\text { Single crystal } \mathrm{Al}_{2} \mathrm{O}_{3} \\
\text { Polycrystalline } \mathrm{YAG} \\
\text { Graded } \mathrm{Al}_{2} \mathrm{O}_{3} \\
\mathrm{Al}_{2} \mathrm{O}_{3} \text { Cermet-5\% Nb } \\
\mathrm{Al}_{2} \mathrm{O}_{3} \text { Cermet-10\% Nb}\end{array}$ \\
\hline
\end{tabular}




\subsection{Postirradiation Examination}

Postirradiation examination of the irradiated samples consisted of a visual examination, dimensional measurements, metallographic examination, He leak check, and electrical resistance as a function of temperature. A flow chart outlining the PIE is shown in Fig. 5-1.

\subsection{Test Results}

The results of the in-reactor tests are summarized in Table 5-2. Detailed information on each of the tests can be found in Refs. 5-1 thru 5-4, and in a larger body of data discussed in Section 1.7.

\subsubsection{Polycrystalline Alumina Taper Seals}

Polycrystalline alumina taper seals were not tested as part of the UCA seal irradiation program but were used in the H-series TFE. Table 5-3 summarizes the testing history of the six H-series TFEs tested idn the TFE Verification Program. This type of seal experienced over 30,000 real time test hours in the TRIGA reactor and remained hermetic up to a fluence of $5 \times 10^{21} \mathrm{n} / \mathrm{cm}^{2}$ in early EBR-II testing as is shown in Fig. 5-2. This type of seal does not meet the TFE-VP lifetime requirement but there is good evidence that its lifetime is at least half of the required 7 year lifetime. Because of the extensive real time experience with the polycrystalline alumina taper seal, this type of seal is considered to be a backup for the insulator seal.

Table 5-3

SUMMARY OF H-SERIES TFE TESTING

\begin{tabular}{||l|c|c|c|c|c|c||}
\hline \multicolumn{1}{|c|}{ Test } & $1 \mathrm{H} 1$ & $1 \mathrm{H} 2$ & $1 \mathrm{H} 3$ & $3 \mathrm{H} 1$ & $3 \mathrm{H} 5$ & $6 \mathrm{H} 1$ \\
\hline Number of Seals & 1 & 1 & 1 & 3 & 3 & 6 \\
Start & $9-88$ & $3-90$ & $8-89$ & $5-91$ & $9-92$ & $4-93$ \\
End & $12-90$ & $3-92$ & $4-92$ & $3-93$ & $10-93$ & $10-93$ \\
Hours & 17,166 & 14,000 & 20,020 & 14,167 & 9,041 & 4,316 \\
Fast Fluence & $6.4 \times 10^{20}$ & $1.4 \times 10^{21}$ & $2.4 \times 10^{21}$ & $1.6 \times 10^{21}$ & $9.3 \times 10^{20}$ & $5.1 \times 10^{20}$ \\
$\mathrm{n} / \mathrm{cm}^{2}$ & $\mathrm{n} / \mathrm{cm}^{2}$ & $\mathrm{n} / \mathrm{cm}^{2}$ & $\mathrm{n} / \mathrm{cm}^{2}$ & $\mathrm{n} / \mathrm{cm}^{2}$ & $\begin{array}{c}\mathrm{n} / \mathrm{cm}^{2} \\
\text { End of Test }\end{array}$ \\
\cline { 2 - 2 } & $\begin{array}{c}\text { Loss of } \\
\text { output }\end{array}$ & $\begin{array}{c}\text { Internal } \\
\text { short }\end{array}$ & $\begin{array}{c}\text { Loss of } \\
\text { output }\end{array}$ & $\begin{array}{c}\text { Heater } \\
\text { failure }\end{array}$ & $\begin{array}{c}\text { Testing } \\
\text { terminated }\end{array}$ & $\begin{array}{c}\text { Testing } \\
\text { terminated }\end{array}$ \\
\hline
\end{tabular}




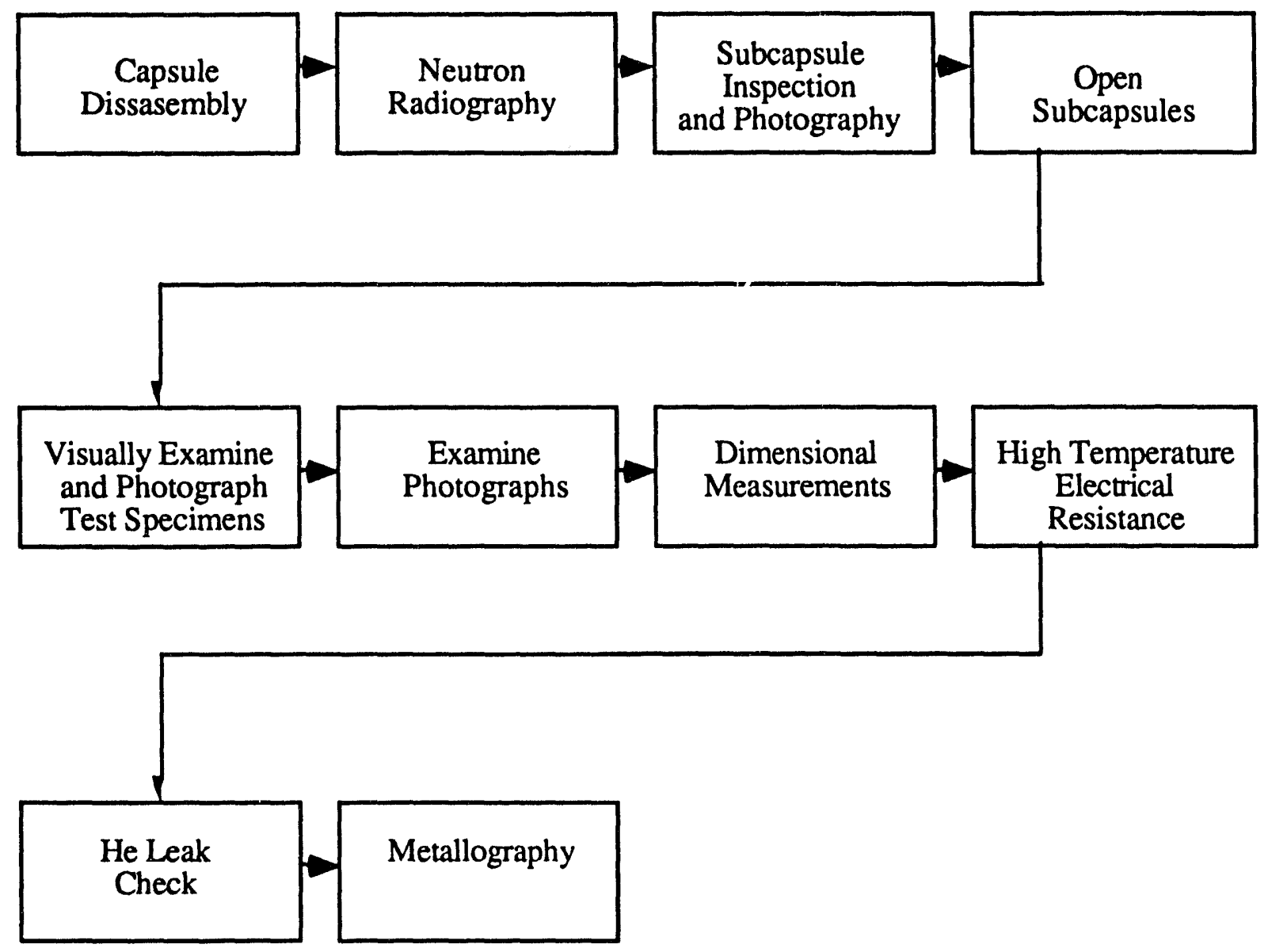

Figure 5-1. Postirradiation Examination Flow Chart

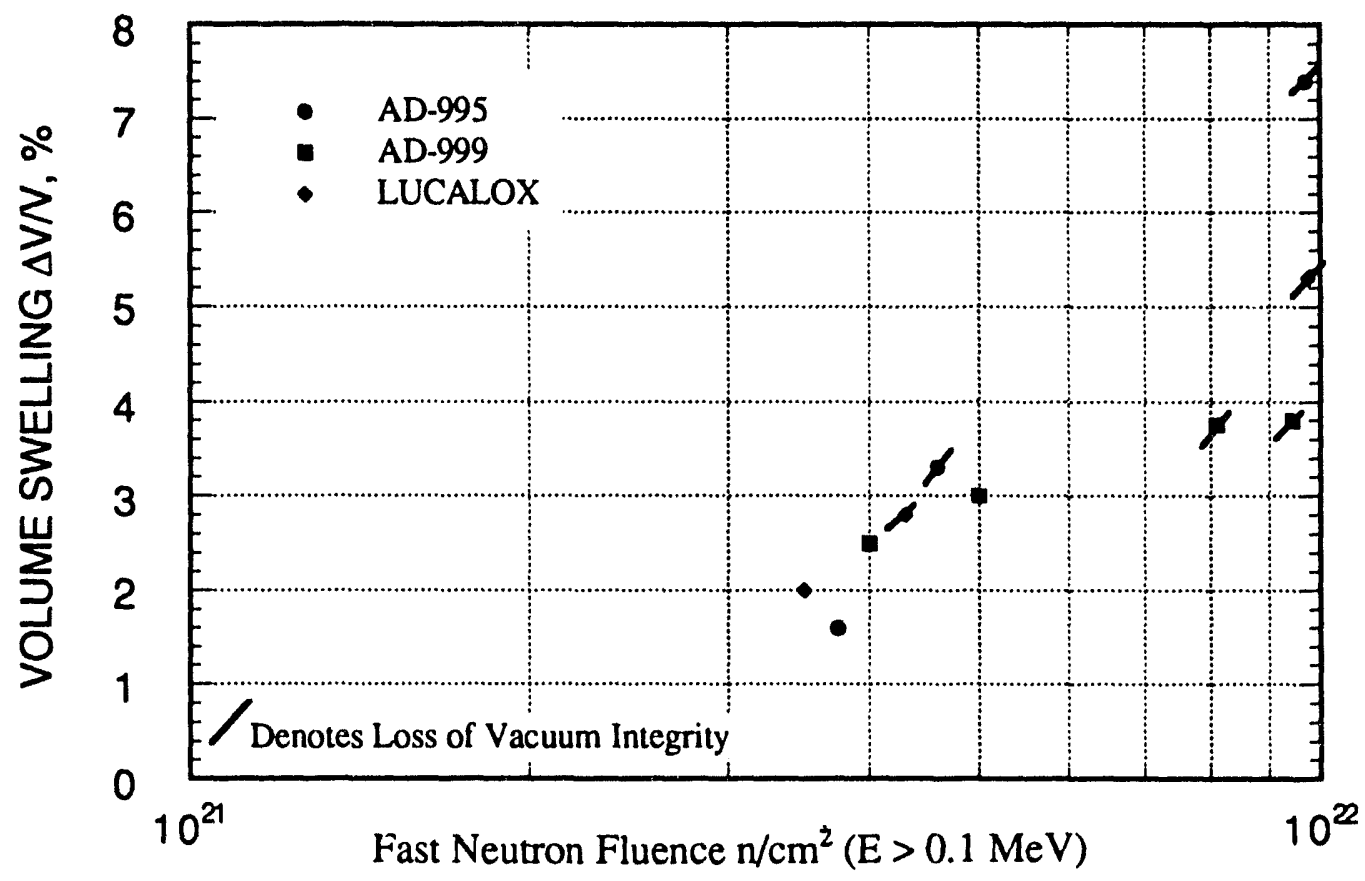

Figure 5-2. Polycrystalline Alumina 1970s EBR-II Irradiation Data 
Table 5-2.

INSULATOR SEAL IN-REACTOR TEST SUMMARY

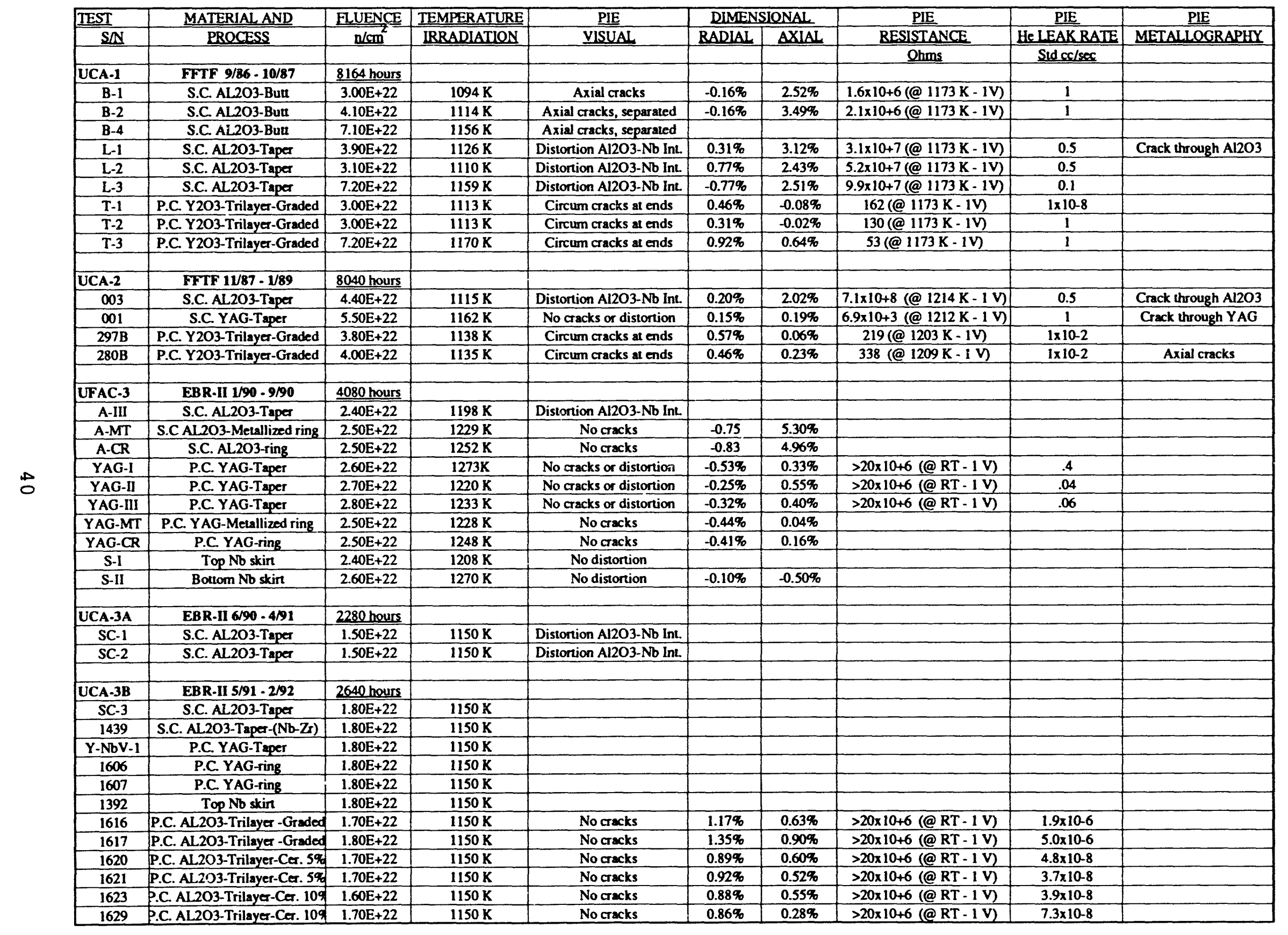




\subsubsection{Single Crystal Alumina Taper Seal}

The single crystal alumina taper seal at the start of the TFE-VP was the reference insulator seal. PIE showed that when these seals were irradiated to a fluence of $>1 \times 10^{22}$ $\mathrm{n} / \mathrm{cm}^{2}$ the seals did not remain hermetic. Neutron radiographs, visual examination and metallography (Fig. 5-3) showed that the ceramic-metal interface was distorted and the ceramic had cracked. UCA-1 was the first in-reactor test that showed this type of damage.

Improvements in the fabrication process, discussed in Section 3.4, were implemented to minimize fabrication induced microcracks for seals tested in UCA-3 Batch A. However, neutron radiographs of Batch A seals showed the same distortion observed in previous reactor tests. Fabrication induced microcracks were not the problem.

A lower temperature braze composition was also not effective in solving the problem. A single crystal alumina taper seal (S/N 1439) with the braze was tested in UCA-3, Batch B to a fluence of $1.8 \times 10^{22} \mathrm{n} / \mathrm{cm}^{2}$. Neutron radiographs showed the same distortion at the ceramic-metal interface. These results and results of irradiation tests on the individual components (UFAC-3) indicated that the distortion and cracking were largely due to the difference in swelling characteristics between the single crystal alumina and the niobium when irradiated to fluences $>1 \times 10^{22} \mathrm{n} / \mathrm{cm}^{2}$. As a result, single crystal alumina taper seal was dropped as the reference insulator seal.

\subsubsection{YAG Taper Seals}

The single crystal YAG taper seal did not exhibit the type of distortion observed with the single crystal alumina taper seals at the ceramic-metal interface. However the seal was not He leak tight and metallography (Fig. 5-4) revealed multiple cracks throughout the ceramic. Because of fabrication difficulties with polycrystalline and single crystal YAG and the fact that none of the seals were He leak tight after irradiation, YAG as an insulator material for the taper seal was not considered further.

\subsubsection{Yttria Trilayer Seals}

The yttria trilayer seals after irradiation had circumferential cracks at each end, but the cracks did not extend all the way through as shown in Fig. 5-5. Yttria trilayer seals showed good He leak tightness but yttria was dropped as a candidate insulator material because of its poor ex-reactor electrical performance.

\subsubsection{Alumina Trilayer Seals}

As with the case with ex-reactor testing, in-reactor testing of the sheath insulator can be used to evaluate the performance of the trilayer seal. Several sheath insulators were tested as part of the UCA irradiation program. The alumina graded and cermet sheath insulators were tested to fluences as high as $7.2 \times 10^{22} \mathrm{n} / \mathrm{cm}^{2}$. These alumina sheath insulators 


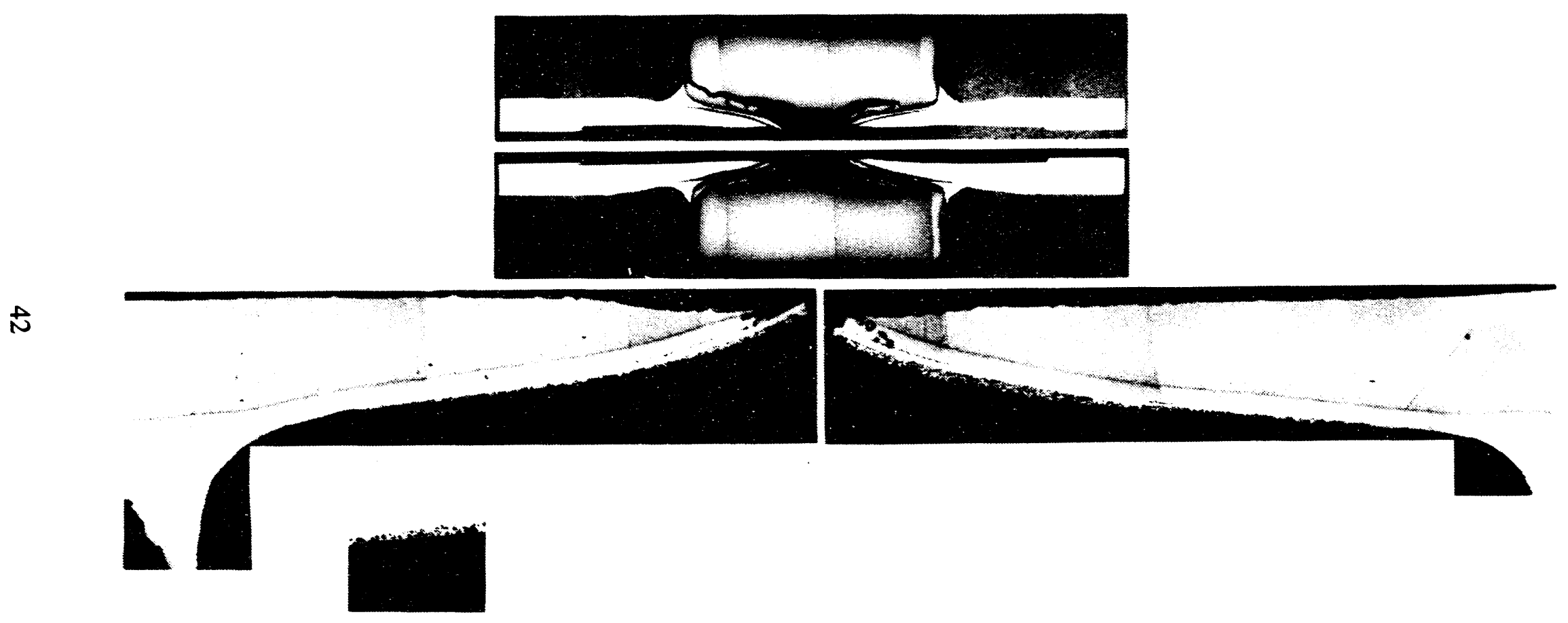

Figure 5-3. Longitudinal Surface of UCA-2 Single Crystal Alumina Taper Seal (S/N 003, Peak Fast Fluence $4.4 \times 10^{22} \mathrm{n} / \mathrm{cm}^{2}$, Irradiation Temperature $1115 \mathrm{~K}$ ). 


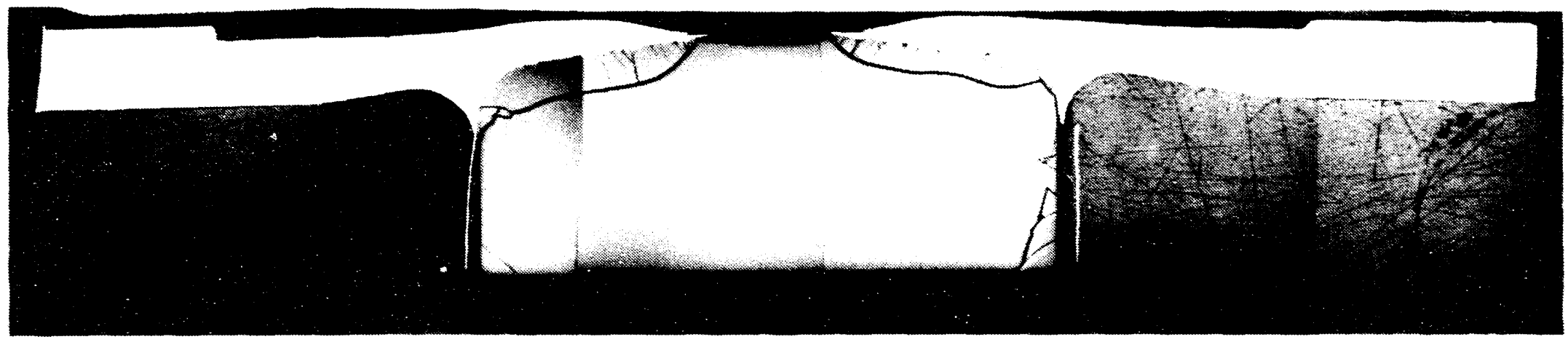

w

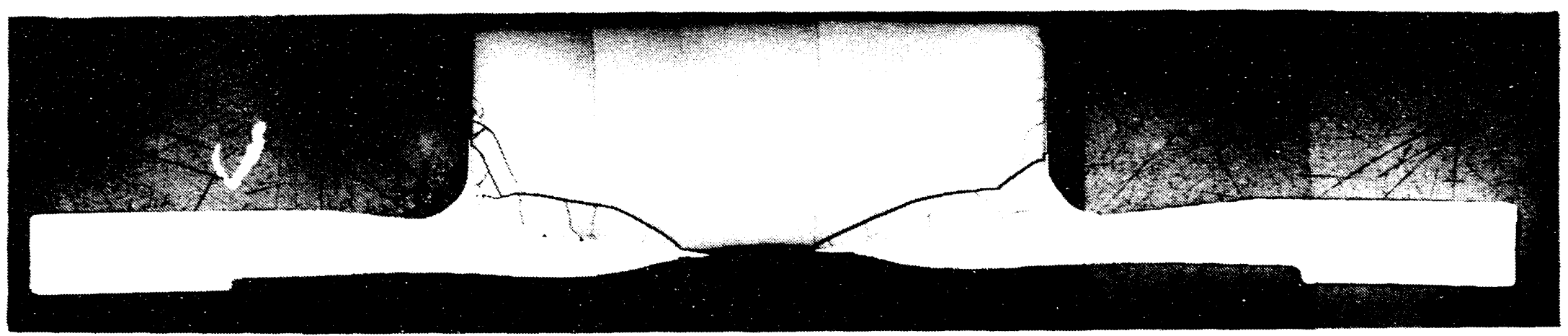

Figure 5-4. Longitudinal Surface of UCA-2 Single Crystal YAG Taper Seal (S/N 001, Peak Fast Fluence $5.5 \times 10^{22} \mathrm{n} / \mathrm{cm}^{2}$, Irradiation Temperature $1120 \mathrm{~K}$ ) 

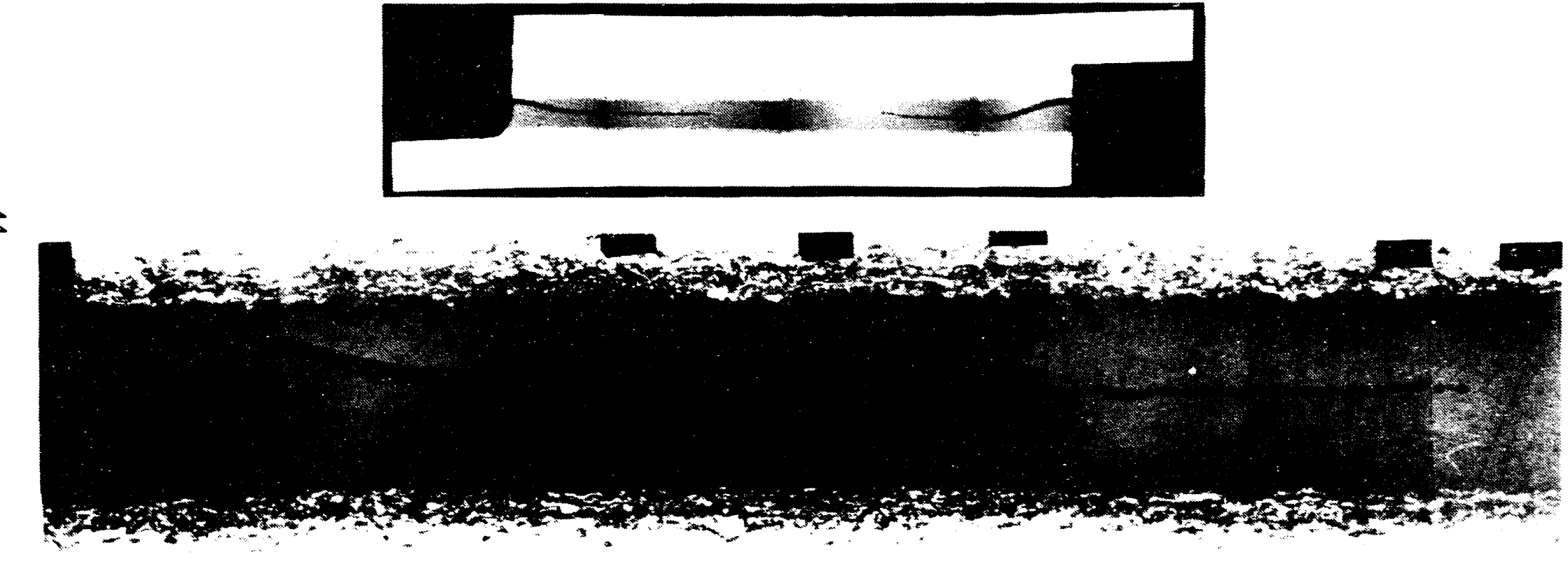

Figure 5-5. Longitudinal Surface of UCA-2 Yttria Trilayer Seal

(S/N $280 \mathrm{~B}$, Peak Fast Fluence $4.0 \times 10^{22} \mathrm{n} / \mathrm{cm}^{2}$, Irradiation Temperature $1135 \mathrm{~K}$ ) 
showed good stability to high fluences. The microstructure of the sheath insulators was similar to their preirradiated appearance with no indication of debonding or cracking at the metal ceramic interface (Figs. 5-6 and 5-7). The alumina sheath insulators retained their high temperature electrical properties after irradiation, and their room temperature He leak tightness was lower than the end-of-life requirement for the insulator seal.

Alumina graded and cermet trilayer seals, having the same thermal expansion convolution and dimensions as the taper seals used in the $\mathrm{H}$-series TFE, were tested in UCA3 Batch B. After irradiation to a fluence of $1.8 \times 10^{22} \mathrm{n} / \mathrm{cm}^{2}$ neutron radiographs and visual examination showed no indications of cracks or distortions. The room temperature electrical resistances were good and the seals were hermetic after irradiation. The alumina trilayer seal (graded or cermet) had the best performance of all the insulator seals tested and met the TFE-VP requirements for the insulator seal. 


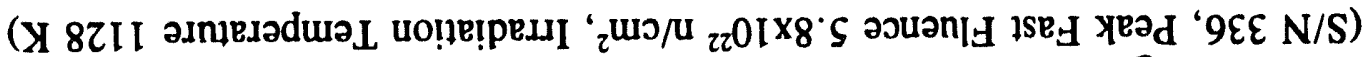

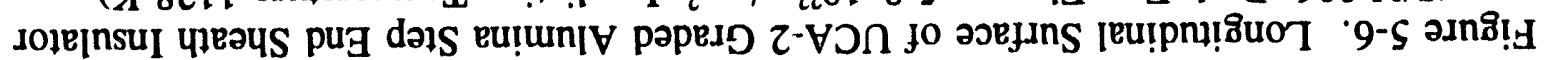
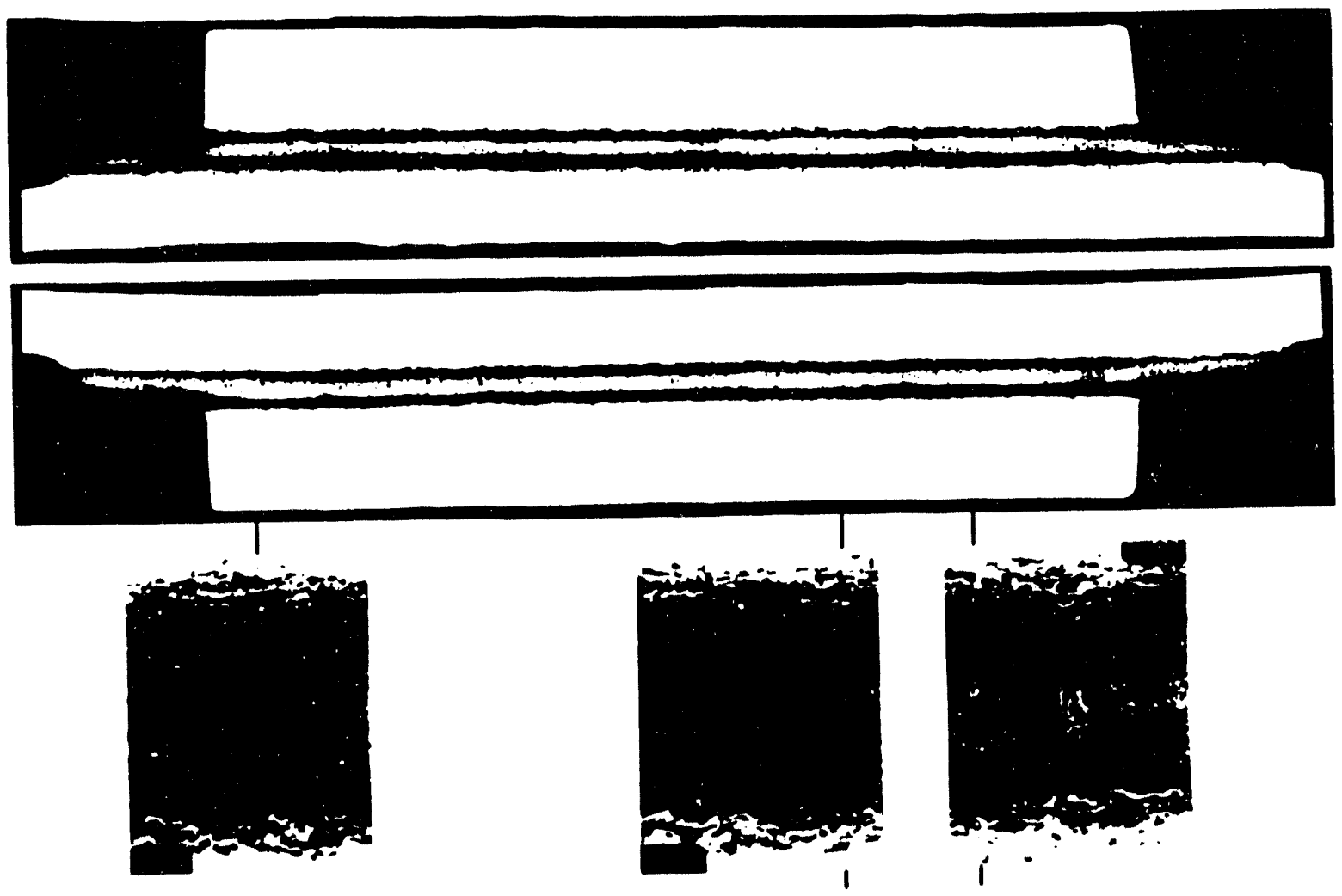

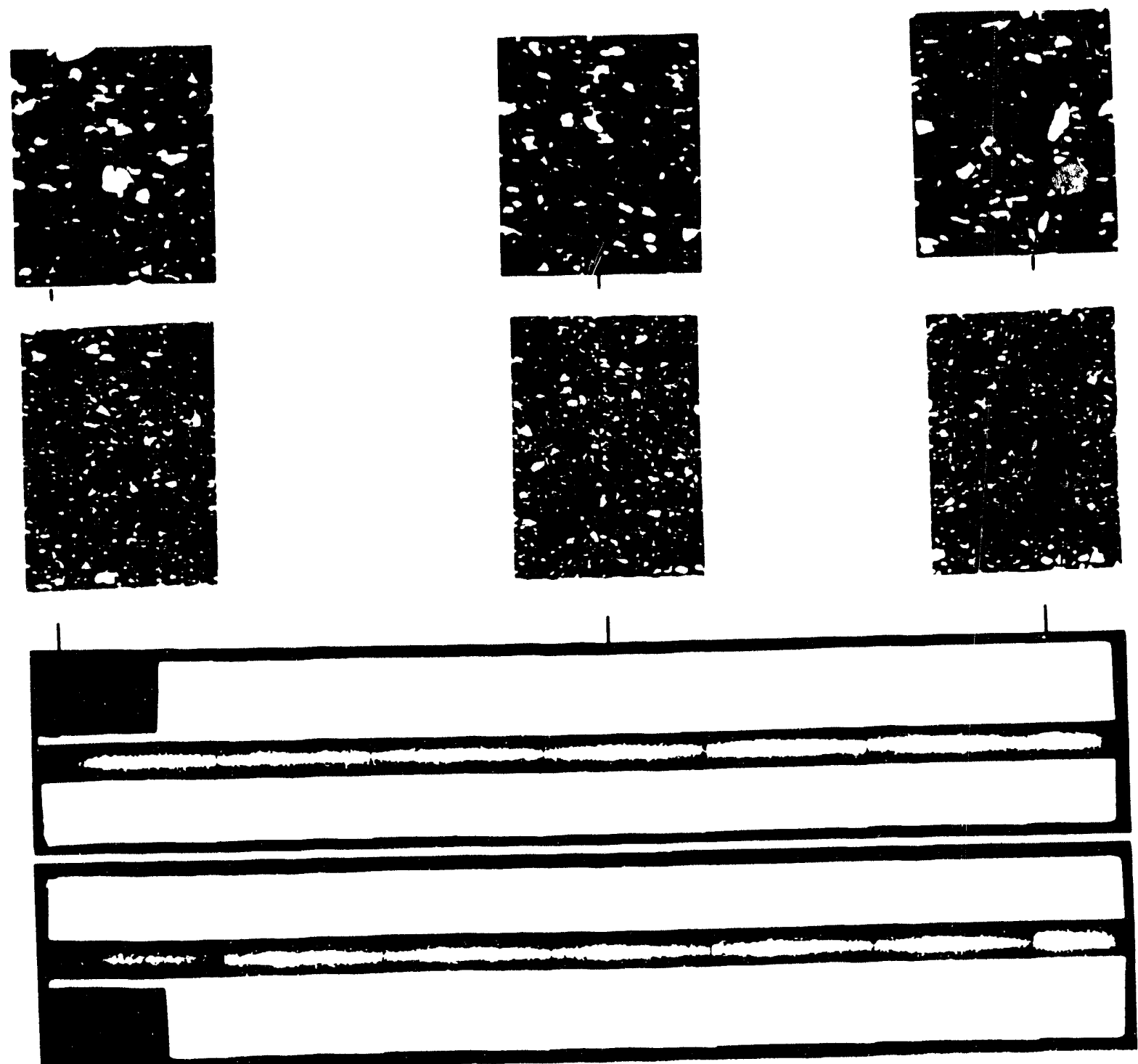

Figure 5-7. Longitudinal Surface of UCA-2 Alumina Cermet (10\% Nb) Square End Sheath Insulator (S/N TA9, Peak Fast Fluence $6.0 \times 10^{22} \mathrm{n} / \mathrm{cm}^{2}$, Irradiation Temperature $1121 \mathrm{~K}$ ) 


\section{INSULATOR SEAL SPECIFICATION}

\subsection{Materials/Design}

below:

The TFE Verification Program reference insulator seal specifications are summarized

\section{Reference Insulator Seal}

Insulator material:

Design:

Fabrication:

\section{Backup Insulator Seal}

Insulator material:

Design:

Fabrication:
Polycrystalline alumina

Trilayer

Plasma sprayed graded or slip cast cermet and gas pressure bonded

Polycrystalline alumina

Taper

Metallized and brazed.

Table 6-1 summarizes the insulator seal development effort.

\subsection{Fabrication Process Description: Reference Insulator Seal}

The insulator in the trilayer shown schematically in Fig. 6-1, is an aluminum oxidematrix composite with niobium powder as the second phase. Two types of aluminum oxidematrix composite insulators can be used: a graded alumina-niobium configuration or an alumina-niobium cermet. The graded configuration uses aluminum oxide-niobium layers of different compositions between the two niobium cylinders. Those layers close to the niobium cylinders have a high niobium content. The middle layer is pure aluminum oxide and is the electrical insulating layer. The graded structure minimizes the stresses resulting from the thermal expansion difference between the aluminum oxide and the niobium. In the cermet, niobium powder is mixed uniformly throughout the aluminum oxide matrix. Additions of niobium powder to the aluminum oxide increases the fracture strength of the oxide, and provides for a good bond between the aluminum oxide and the niobium cylinders. The cermet better matches the coefficient of thermal expansion of niobium than pure aluminum oxide.

\subsubsection{Materials}

The reference materials selected for the insulator seal trilayer are:

Insulator: Polycrystalline aluminum oxide (Linde A or Linde B from Union Carbide for the graded structure and A39SG from Alcoa for the cermet). 
Table 6-1

INSULATOR SEAL DEVELOPMENT EFFORT

\begin{tabular}{|c|c|c|c|c|c|c|c|c|c|c|}
\hline \multirow[b]{2}{*}{ Material } & \multirow[b]{2}{*}{ Design } & \multirow[b]{2}{*}{$\begin{array}{r}\text { Electrical } \\
\text { Properties }\end{array}$} & \multirow[b]{2}{*}{ Neutron Stability } & \multirow[b]{2}{*}{ Fabricability } & \multicolumn{6}{|c|}{ Test Matrix (No. of Specimens) } \\
\hline & & & & & UCA-1 & UCA-2 & UFAC-3 & UCA-3 & $\begin{array}{c}\text { TFE } \\
1 \mathrm{H} 1,1 \mathrm{H} 2, \\
1 \mathrm{H} 3,3 \mathrm{H} 1, \\
3 \mathrm{H} 5,6 \mathrm{H} 1\end{array}$ & $\begin{array}{l}\text { SP-100 } \\
\text { Fueled } \\
\text { Emitter }\end{array}$ \\
\hline Alumina & Taper SC & Good & Poor & Good & 3 & 1 & 1 & 4 & & \\
\hline Alumina & Butt SC & Good & Poor & Poor & 3 & & & & & \\
\hline YAG & Taper SC & Good & Poor & Poor & & 1 & & & & \\
\hline Alumina & Taper PC & Good & Acceptable* & Good & & & & & 15 & 9 \\
\hline YAG & Taper PC & Good & Poor & Poor & & & 3 & 1 & & \\
\hline Alumina & Trilayer Graded & Good & Good & Good & & & & 2 & & \\
\hline Alumina & Trilayer Cermet & Good & Good & Good & & & & 4 & & \\
\hline Yturia & Trilayer Graded & Poor & Poor & Good & 3 & 2 & & & & \\
\hline
\end{tabular}

PC Polycrystalline

SC Single crystal

* Good to a fluence of $5 \times 10^{21} \mathrm{n} / \mathrm{cm}^{2}(\mathrm{E}>0.1 \mathrm{MeV})$ 


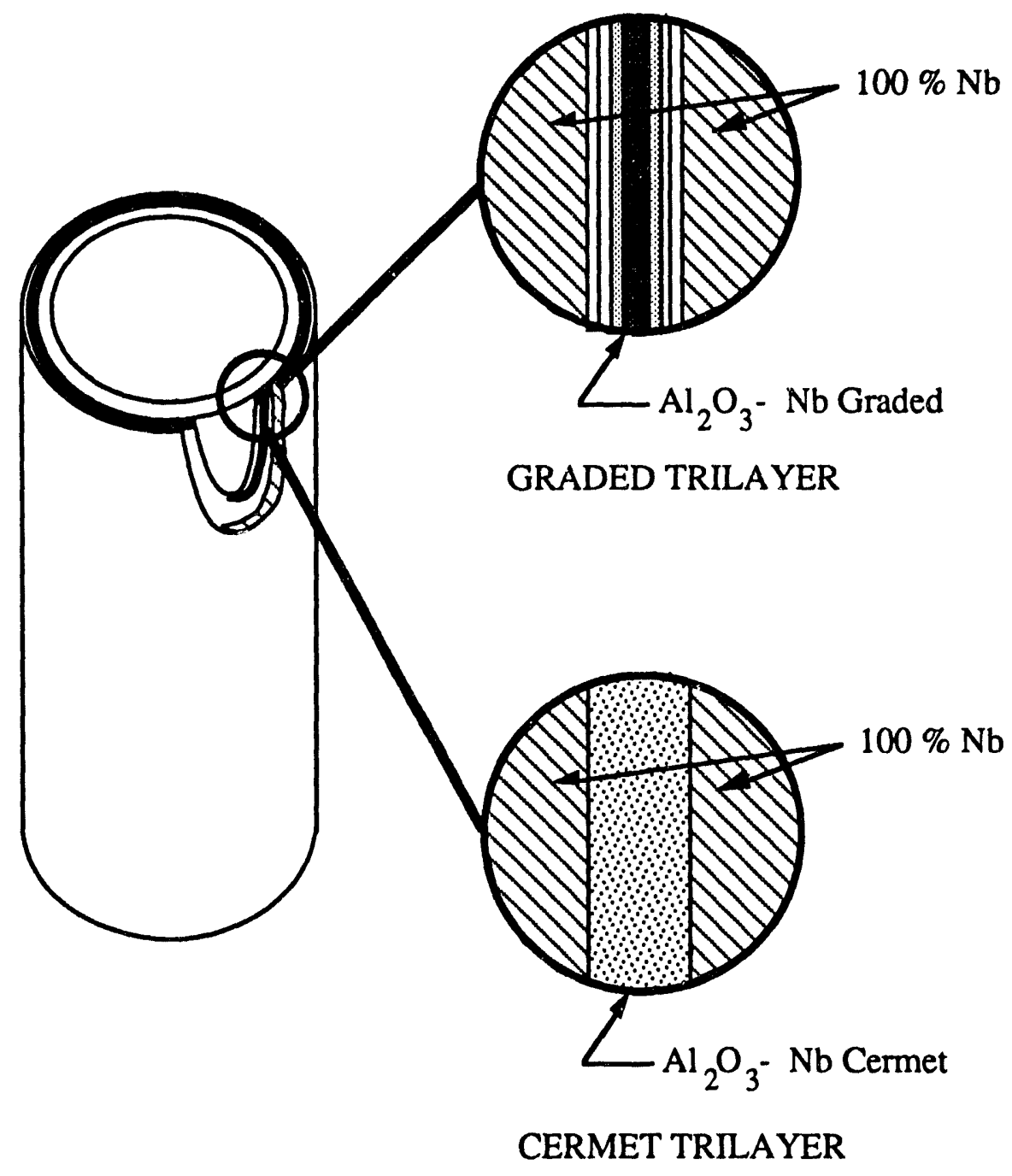

Figure 6-1. Insulator Seal Trilayer Configuration

Metal: $\quad$ Niobium rod and tube.

Niobium powder: $(<10 \mu \mathrm{m}$ FSSS Hermann C. Starck)

\subsubsection{Processing}

Machining niobium and aluminum oxide-matrix composites should be done with sulfur free cutting fluids. oxides.

Niobium parts should be solvent and acid cleaned to remove hydrocarbons and 
For the plasma sprayed process, the niobium surface to be plasma sprayed should be conditioned by grit-blasting with ALCOA tabular alumina. Typical plasma spraying parameters are specified as follows:

o Gun current setting:

400 amps

o Gun distance from work piece: 2 to 3 inches

o Torch gas:

o Powder carrier gas:

Argon at $70 \mathrm{CFH}$

Argon

For the cermet process, cermet tubes are fabricated by slip casting the alumina niobium mixture.

Gas pressure bonding of the graded and cermet trilayer designs should be done following the temperature-pressure-time cycle given in Fig. 6-2.
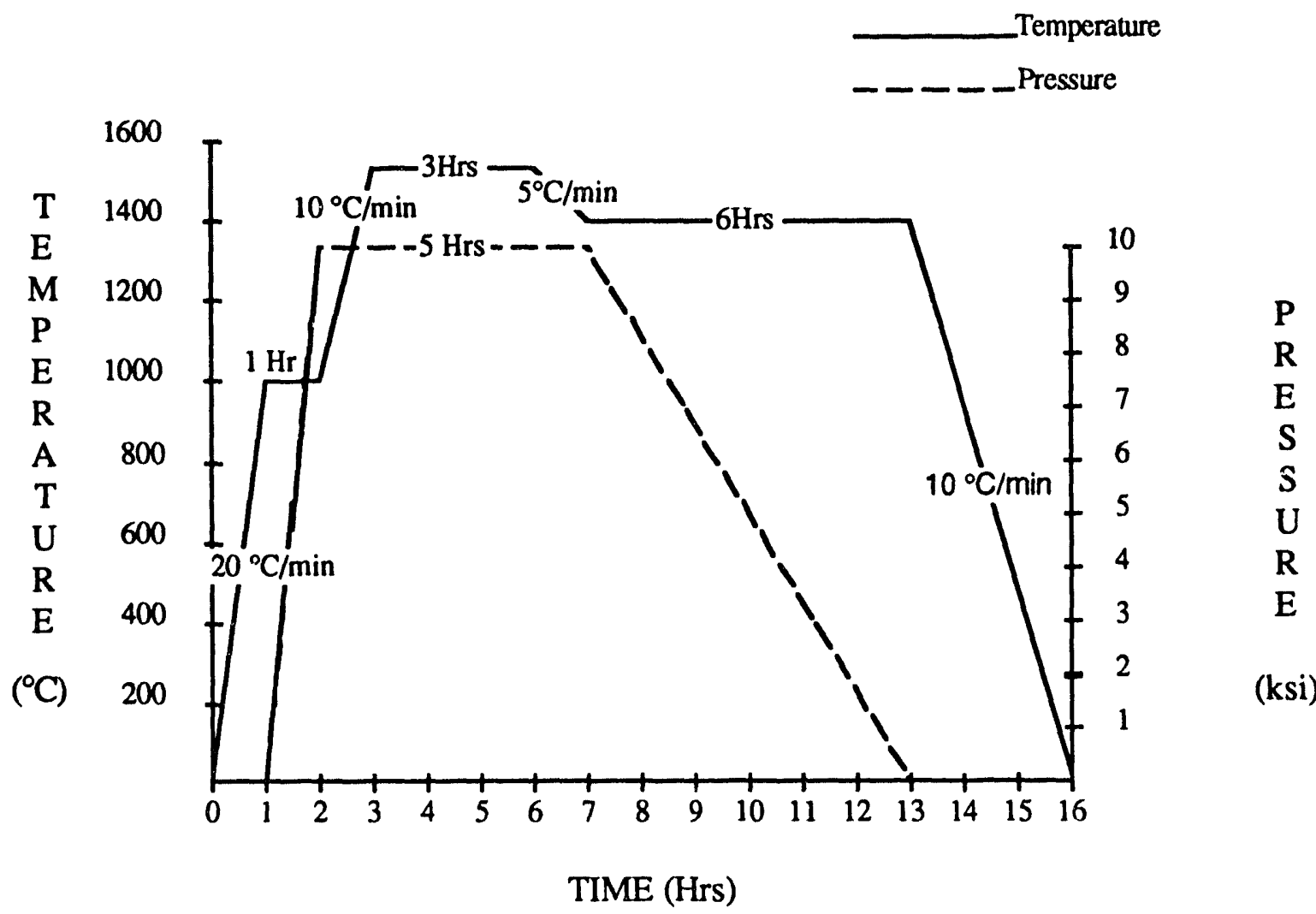

Figure 6-2. Gas Pressure Bonding Cycle for Trilayer Seals 


\subsubsection{Acceptability of Trilayer Insulator Seals}

The trilayer insulator seals should pass the following acceptability criteria:

1) Seal dimensions should be acceptable.

2) Leak rate must be below $2 \times 10^{-11} \mathrm{std} \mathrm{cc} / \mathrm{sec}$ of $\mathrm{He}$.

3) After thermal cycling three times to $1200^{\circ} \mathrm{C}$ in a vacuum of better than $2 \times 10^{-7}$ torr, the leak rate must be below $2 \times 10^{-11} \mathrm{std} \mathrm{cc} / \mathrm{sec}$ of $\mathrm{He}$.

4) Electrical resistance of seal should be greater than $1000 \mathrm{ohms.}$

\subsection{Fabrication Process Description: Backup Insulator Seal}

The backup insulator seal is taper insulator seal. The taper seal consists a ceramic ring brazed to two niobium rings (skirts). Braze wetting and adherence to the ceramic is provided by a metallizer layer on the ceramic.

\subsubsection{Materials}

The materials selected for the taper insulator seal are:

o Insulator rings: Polycrystalline aluminum oxide, $>99.5 \%$ purity and

$>98 \%$ dense.

o Metal rings: Niobium.

o Metallizer: Tungsten-2\% yttria

o Braze: $\quad$ Niobium-vanadium alloy, $(35 \% \mathrm{Nb}-65 \% \mathrm{~V})$.

\subsubsection{Processing}

Machining niobium and aluminum oxide rings should be done with sulfur free cutting fluids.

Niobium parts and ceramic rings should be solvent and acid cleaned.

Ceramic rings should be inspected and any cracks, voids, linear defects, or large uncleanable discolorations are sufficient for rejection.

Ceramic rings are metallized with a tungsten-yttria metallized prior to seal fabrication.

An intermediate CVD tungsten coating is applied between the metallizer and braze. 
The metallized and coated ring should be brazed to the niobium skirts using the $\mathrm{Nb}$ $\mathrm{V}$ braze alloy.

\subsubsection{Acceptability of Taper Insulator Seals}

Taper insulator seals should pass the following acceptability criteria:

1) Seals dimensions should be acceptable.

2) Leak rate must be below $2 \times 10^{11}$ std $\mathrm{cc} / \mathrm{sec}$ of $\mathrm{He}$.

3) After thermal cycling three times to $1200^{\circ} \mathrm{C}$ in a vacuum of better than $2 \times 10^{-7}$ torr, the leak rate must be below $2 \times 10^{-11} \mathrm{std} \mathrm{cc} / \mathrm{sec}$ of He.

4) One sample from each batch should be peel tested, and peel strength should be greater than $20 \mathrm{lb} /$ inch.

5) Electrical resistance of seal should be greater than $1000 \mathrm{ohms}$. 


\section{REFERENCES}

1-1 General Atomics Report GA-C18062, GES Baseline System Definition and Characterization Study, Final Report for the Period December 1984 through July 1985; Prepared under JPL Contract 956472, August 9, 1985.

1-2 General Atomics Report GA-A18182 (1985), SP-100 Thermionic Technology Program Annual Integrated Technical Progress Report for the Period Ending September 30, 1985, by GA Technologies, Rasor Associates, Inc., Space Power, Inc. and Thermo Electron Corporation, General Atomics, San Diego, CA, November 1985.

1-3 General Atomics Report GA-A18915 (1987), Thermionic Irradiations Program Final Report, General Atomics, San Diego, CA.

1-4 Cone, V. P. and J. Dunlay (1987), Thermionic Technology Program Fiscal Year 1986 and Final Technical Report, Thermo Electron Report No. TE4400-227-87.

1-5 Hatch, G. L. (1988), Thermionic Technology Program: Thermionic Converter Performance Final Report, NSR-25-25, E-533-003-B053188 (DOE Contract No. DE-ACO3-86SF15954).

3-1 Clinard, F.W., "Ceramics for Application Fusion Systems," J. Nucl. Mater. $\underline{85}$ and $\underline{86}, 393,1979$.

3-2 Touloukian, Y.S., R.K. Kirby, R.E. Taylor and T.Y.R. Lee, "Thermophysical Properties of Matter," Vol. 13: Thermal Expansion of Nonmetallic Solids (1977), Plenum, New York.

3-3 Bates, J.L., and J.E. Garnier, "Electrical Conductivity of $\mathrm{MgAl}_{2} \mathrm{O}_{4}$ and $\mathrm{Y}_{2} \mathrm{O}_{3}$,"Comm. of Am. Ceram. Soc. C-138, 1981.

3-4 Brook, R.L., J. Yee, and F.A. Kroger, "Electrochemical Cells and Electrical Conduction of Pure and Doped $\mathrm{Al}_{2} \mathrm{O}_{3}$,"J. Am. Ceram. Soc. 54, 444, 1971.

3-5 Bauer, A.W., and J.L. Bates, "An Evaluation of Electrical Insulators for Fusion Reactors," Battelle Report BMI-1930, 1974.

3-6 Gupta,T.K. and J. Valentich, "Thermal Expansion of Yttrium Aluminum Garnet," J. Am. Ceram. Soc. 54, 355, 1971.

3-7 Lin-Liu, Y.R. and L.D. Woolf, "Site Percolation and Electrical Breakdown in Cermets," GA Technologies Report GA-D18628, 1986. 
4-1 Kroger, F.A., "Electrical Properties of a $\mathrm{Al}_{2} \mathrm{O}_{3}$," Advances in Ceramics, Vol. 10, Structure and Properties of $\mathrm{MgO}$ and $\mathrm{Al}_{2} \mathrm{O}_{3}$ Ceramics, pp. 1-15, (The American Ceramic Society, 1984).

5-1 Lawrence, L.A., N.S. Cannon, and K.E. Ard, "Irradiation and Examination of the Thermionic Fuel Element (TFE) Verification Program UCA-1 Samples," WHC-SP0585, June, 1990.

5-2 Lawrence, L.A., K.E. Ard, and D.M. Paxton, "Irradiation and Examination of the Thermionic Fuel Element (TFE) Verification Program UCA-2 Samples," WHC-SP0656, June, 1991.

5-3 Paxton, D.M., and L.A.Lawrence,"Irradiation and Nondestructive Examination (NDE) of the Thermionic Fuel Element (TFE) Verification Program UFAC SC3-2 Seal Insulator Samples," WHC-SP-0674, June, 1991.

5-4 Lawrence, L.A., and D.M.Paxton, "Irradiation and Examination of the Thermionic Fuel Element (TFE) Verification Program UCA-3 Samples," WHC-SP-1055, September, 1993. 


\section{APPENDIX A}

\section{HE LEAK TIGHTNESS REQUIREMENT}

The maximum allowable leak rate for an insulator seal in a TFE can be estimated using the criterion that the Cs mass loss due to the leak should cause negligible Cs pressure change within a loading stage. The criterion assumed was that the leak tightness of an irradiated seal should be such that the cesium leakage should not result in a drop in cesium pressure of more than 1 torr at the end-of-life. This means that the reservoir size and cesium loading point must be considered in assessing the acceptability of a leak in the seal.

If the idealized isotherms for intercalated Cs-graphite are used in conjunction with the following assumptions:

1) 3 torr cesium pressure,

2) free molecular flow,

3) no fission product gases, and

4) seven year lifetime,

then the maximum allowable leak rate is that shown in Fig. A-1. For example, if the insulator seal in a single cell TFE has a leak rate of $7 \times 10^{-5} \mathrm{std} \mathrm{cc} / \mathrm{sec}$, a Cs reservoir containing 0.2 grams of graphite should be loaded to the first stage to ensure a 7 year lifetime. If third stage loading were desirable (e.g., for temperature considerations), then about 1 gram of graphite would be needed.

An acceptable leak rate at this time is $5 \times 10^{-5} \mathrm{std} \mathrm{cc} / \mathrm{sec}$. 


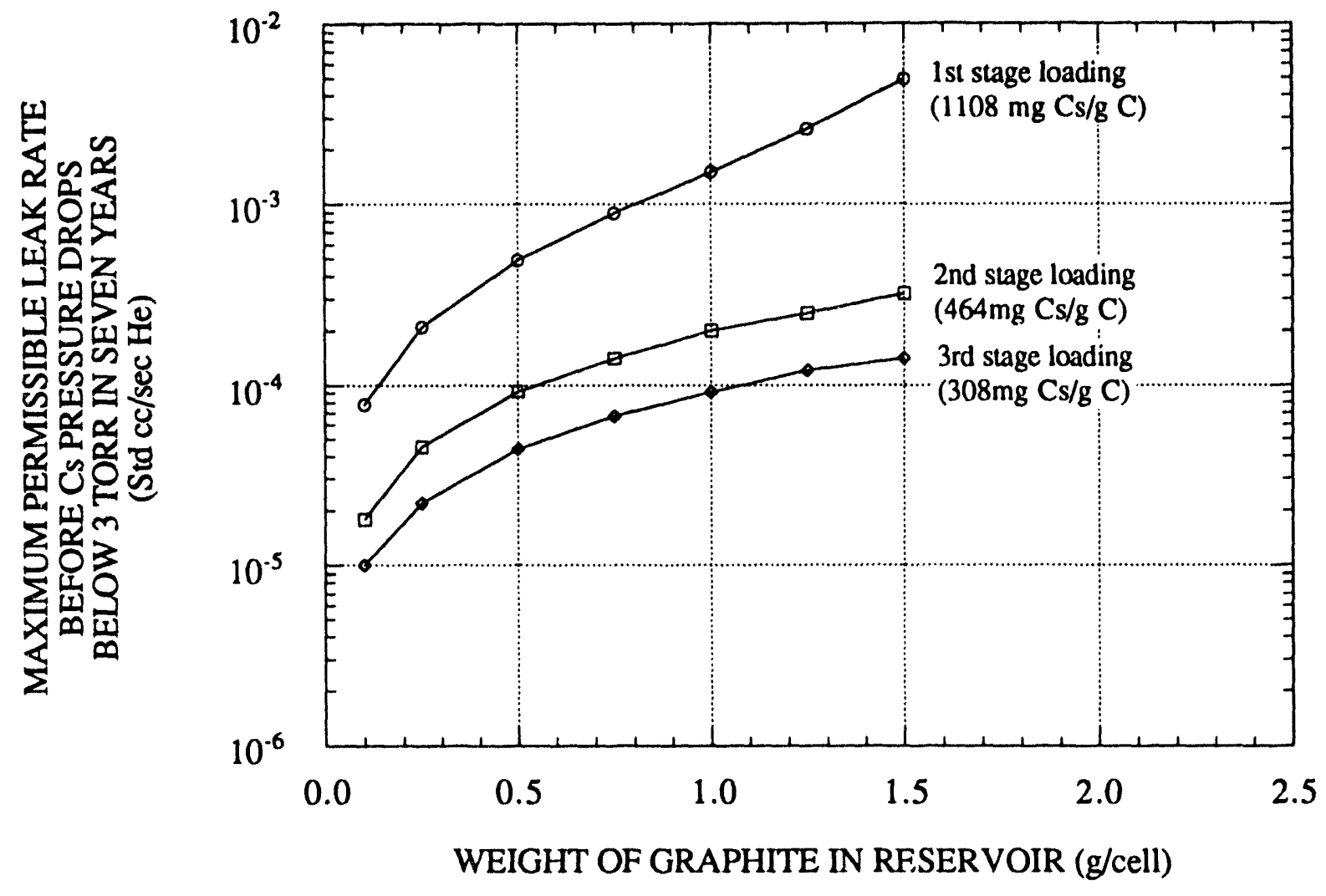

Figure A-1. Insulator Seal He Leak Rate Requirement 


\section{APPENDIX B}

\section{RESISTANCE REQUIREMENT}

The resistance requirement of the insulator seal is such as to limit the total power dissipated in the insulator to $.1 \%$ of total TFE power. The system design assumptions used to calculate the resistance were:

o Converters per TFE: $\quad \mathrm{N}=12$

o Converter voltage:

$$
\begin{array}{ll}
\text { Nominal: } & \mathrm{V}_{\text {CELL }}=0.49 \text { volts } \\
\text { Maximum: } & \mathrm{V}_{\text {CELL }}=0.63 \text { volts }
\end{array}
$$

o TFE current:

$I_{\text {CELL }}=140$ amps

o TFE voltage:

$\mathrm{V}_{\text {TFE }}=5.9$ volts

o TFE power:

$\mathrm{P}_{\text {TFE }}=829$ watts

o Temperature:

$$
\mathrm{T}_{\mathrm{MAX}}=1150 \mathrm{~K}
$$

In the reactor converter system design, the TFEs will be connected in a series and parallel configuration with a maximum of two TFEs connected in series. In such an arrangement the maximum output voltage will be about 15 volts, with a nominal 11.8 volts.

During initial startup of the reactor an open circuit voltage of up to 1.5 volts per converter can be generated during short periods of time. With careful control of the startup procedure, the open circuit voltage can be controlled so that it does not exceed the maximum converter output voltage.

To calculate the insulator seal minimum resistance requirement, the following parameters were used, assuming 2 TFEs are connected in series:

$$
\begin{array}{ll}
0 & \mathrm{~V}_{\text {MAX }}=15 \text { volts } \\
0 & \mathrm{P}_{\text {MAX }}=1658 \text { watts } \\
0 & \mathrm{~N}_{\operatorname{MAX}}=24
\end{array}
$$

The equivalent circuit for the insulator seal calculations is: 


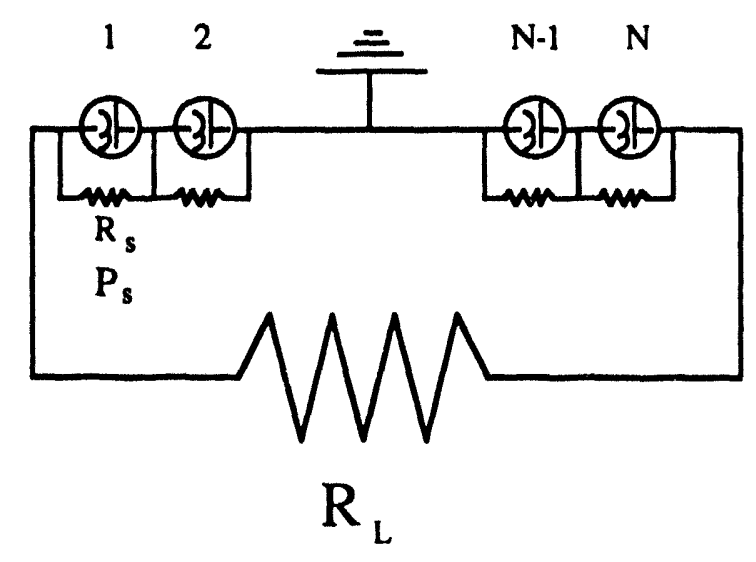

If the allowed total power dissipated by the insulator seals $\left(\mathrm{P}_{\mathrm{Ts}_{\mathrm{s}}}\right)$ is not to exceed $0.1 \%$ of the maximum total TFE power $\left(\mathrm{P}_{\max }\right)$, then:

$$
\begin{array}{ll}
0 & \mathrm{P}_{\mathrm{Ts}}=0.001 \mathrm{P}_{\mathrm{MAX}} \\
0 & \mathrm{P}_{\mathrm{Ts}}=\mathrm{P}_{\mathrm{s}}\left(\mathrm{N}_{\mathrm{MAX}}\right) \\
0 & \mathrm{P}_{\mathrm{s}}=\left(\mathrm{V}_{\mathrm{CELL}}\right)^{2} / \mathrm{Rs} \\
0 & \mathrm{~V}_{\mathrm{CELL}}=\mathrm{V}_{\mathrm{MAX}} / \mathrm{N}_{\mathrm{MAX}} \\
0 & \mathrm{R}_{\mathrm{s}}=\left(\mathrm{V}_{\mathrm{MAX}}\right)^{2} /\left[\mathrm{N}_{\mathrm{MAX}}(0.001) \mathrm{P}_{\mathrm{MAX}}\right]
\end{array}
$$

The resistance requirement for the insulator seal for the TFE-VP is 6 ohms. The resistivity requirement for the insulator material in an insulator seal with a $10 \mathrm{ohm}$ resistance has been calculated for the taper seal and trilayer seals and is given in Fig. B-1. 


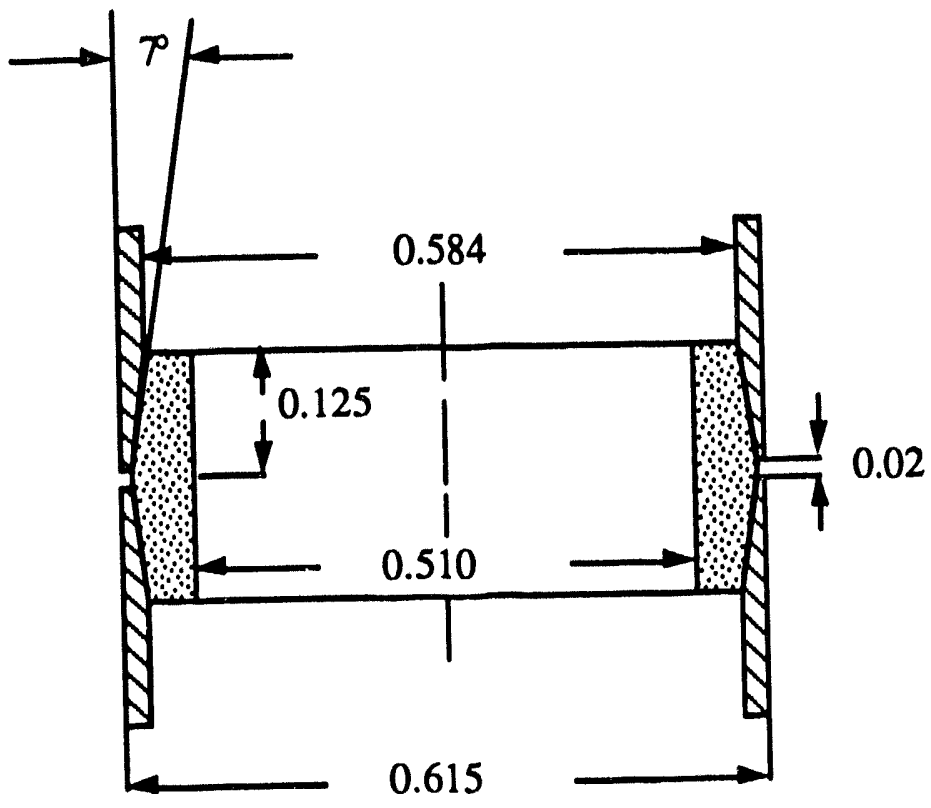

$$
\begin{aligned}
& A=.218 \mathrm{in}^{2}=1.406 \mathrm{~cm}^{2} \\
& \mathrm{~L}=0.136 \mathrm{in}=0.345 \mathrm{~cm} \\
& \mathrm{r}=2.44 \times 10^{1} \mathrm{Ohm}-\mathrm{cm}
\end{aligned}
$$

Taper insulator seal

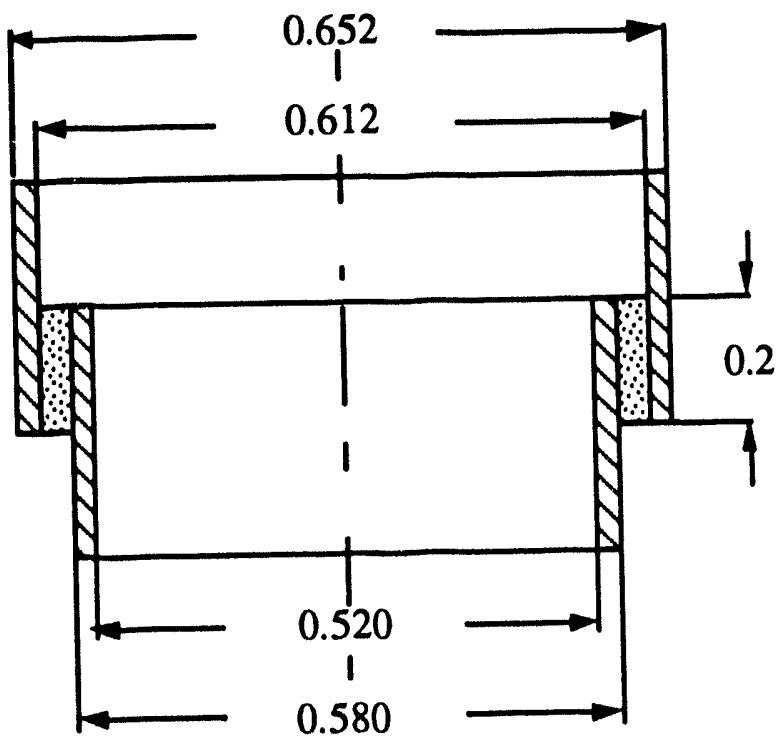

$$
\begin{aligned}
& \mathrm{A}=.374 \mathrm{in}^{2}=2.413 \mathrm{~cm}^{2} \\
& \mathrm{~L}=0.016 \mathrm{in}=0.041 \mathrm{~cm} \\
& \mathrm{r}=3.57 \times 10^{2} \mathrm{Jmm}-\mathrm{cm}
\end{aligned}
$$

Trilayer Insulator seal

Figure B-1. Resistivity Requirements for Taper and Trilayer Insulator Seals 

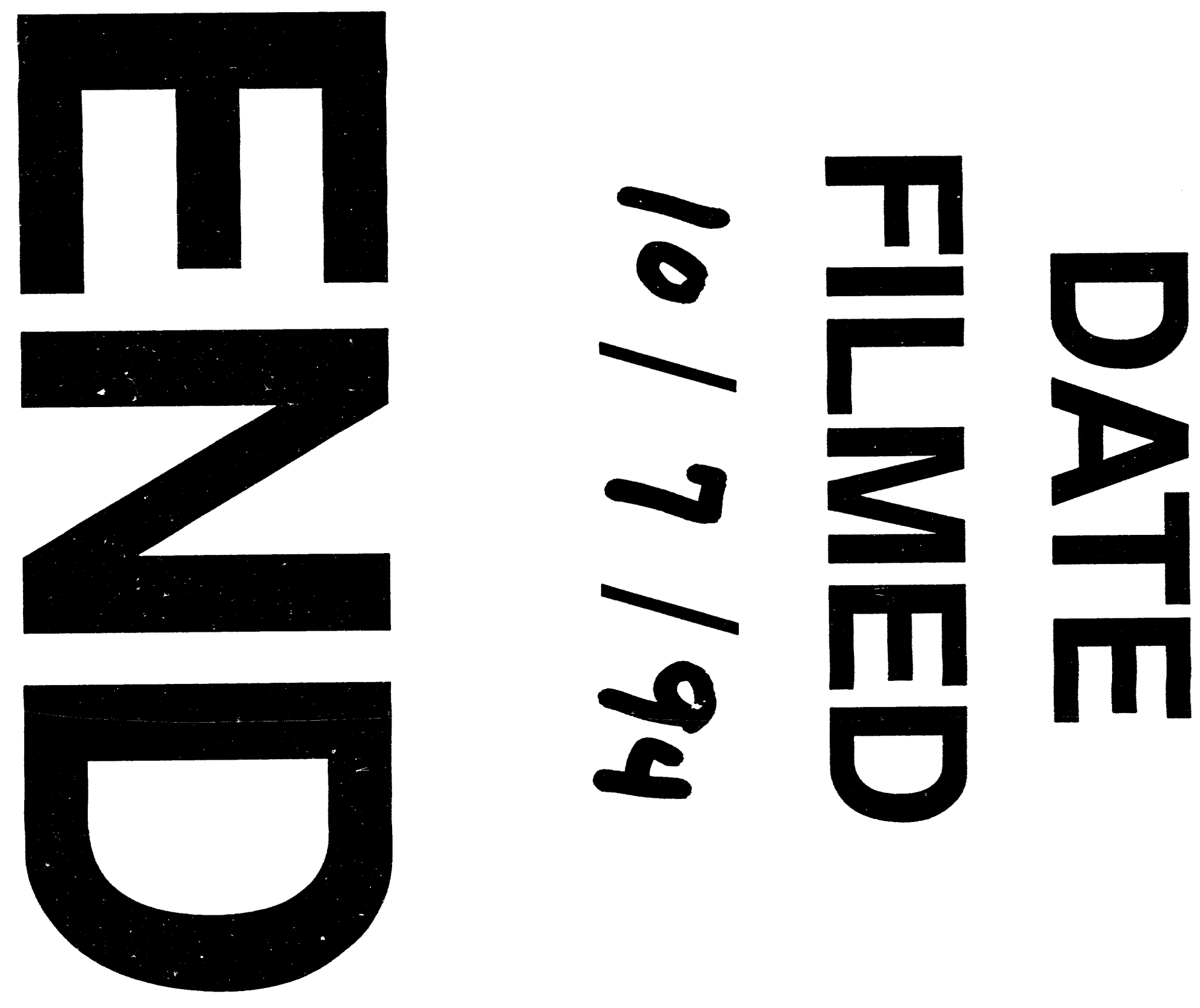
